University of South Florida

DIGITAL COMMONS

Digital Commons @ University of

@ UNIVERSITY OF SOUTH FLORIDA

South Florida

$1-1-2013$

\title{
2013 Accountability Report USF St. Petersburg
}

USF

Follow this and additional works at: https://digitalcommons.usf.edu/usf_accountability_reports

\section{Scholar Commons Citation}

USF, "2013 Accountability Report USF St. Petersburg" (2013). USF Accountability Reports. 35.

https://digitalcommons.usf.edu/usf_accountability_reports/35

This Article is brought to you for free and open access by the USF Archives at Digital Commons @ University of South Florida. It has been accepted for inclusion in USF Accountability Reports by an authorized administrator of Digital Commons @ University of South Florida. For more information, please contact digitalcommons@usf.edu. 


\section{2-13 \\ Annual Accountability Report}

\section{UNIVERSITY OF SOUTH FLORIDA ST. PETERSBURG}

STATE UNIVERSITY SYSTEM of FLORIDA Board of Governors 


\section{$\underline{\text { TABLE OF CONTENTS }}$}

\section{EXECUTIVE SUMMARY}

DASHBOARD

p. 2

KEY ACHIEVEMENTS

p. 5

NARRATIVE

p. 7

\section{DATA TABLES}

SECTION 1. FINANCIAL RESOURCES p. 15

SECTION 2. PERSONNEL p. 19

SECTION 3. ENROLLMENT p. 20

SECTION 4. UNDERGRADUATE EDUCATION p. 22

SECTION 5. GRADUATE EDUCATION p. 31

SECTION 6. RESEARCH \& ECONOMIC DEVELOPMENT p. 33 


\section{Dashboard}

\begin{tabular}{|c|c|c|c|c|c|c|c|c|}
\hline $\begin{array}{l}\text { Headcount } \\
\text { Enrollments }\end{array}$ & $\begin{array}{l}\text { Fall } \\
2012\end{array}$ & $\begin{array}{c}\% \\
\text { Total }\end{array}$ & $\begin{array}{l}2007-2012 \\
\% \text { Change }\end{array}$ & \multicolumn{3}{|c|}{ Degree Programs Offered } & \multicolumn{2}{|c|}{2012 Carnegie Classifications } \\
\hline TOTAL & 4,690 & $100 \%$ & $30 \%$ & \multirow{2}{*}{\multicolumn{2}{|c|}{$\begin{array}{l}\text { TOTAL (as of Spring 2013) } \\
\text { Baccalaureate }\end{array}$}} & 38 & \multirow{2}{*}{ Basic: } & \multirow{2}{*}{$\begin{array}{l}\text { Master's Colleges and } \\
\text { Universities (medium) }\end{array}$} \\
\hline White & 3,317 & $71 \%$ & $16 \%$ & & & 27 & & \\
\hline Hispanic & 585 & $12 \%$ & $124 \%$ & \multicolumn{2}{|l|}{ Master's } & 11 & \multirow{2}{*}{$\begin{array}{l}\text { Undergraduate } \\
\text { Instructional Program: }\end{array}$} & \multirow{2}{*}{$\begin{array}{l}\text { Balanced arts \& sciences, } \\
\text { professions, some graduate }\end{array}$} \\
\hline Black & 435 & $9 \%$ & $82 \%$ & \multicolumn{2}{|l|}{ Research Doctorate } & 0 & & \\
\hline Other & 353 & $8 \%$ & $42 \%$ & \multicolumn{2}{|c|}{ Professional Doctorate } & 0 & \multirow{2}{*}{$\begin{array}{l}\text { Graduate } \\
\text { Instructional Program: }\end{array}$} & \multirow{2}{*}{$\begin{array}{l}\text { Post-baccalaureate with arts } \\
\text { \& sciences (education dominant) }\end{array}$} \\
\hline Full-Time & 2,930 & $62 \%$ & $59 \%$ & \multirow{2}{*}{$\begin{array}{c}\text { Faculty } \\
\text { (Fall 2012) }\end{array}$} & \multirow{2}{*}{$\begin{array}{l}\text { Full- } \\
\text { Time }\end{array}$} & \multirow{2}{*}{$\begin{array}{l}\text { Part- } \\
\text { Time }\end{array}$} & & \\
\hline Part-Time & 1,760 & $38 \%$ & $0 \%$ & & & & \multirow{2}{*}{ Size and Setting: } & \multirow{2}{*}{$\begin{array}{l}\text { Small four-year, primarily } \\
\text { nonresidential }\end{array}$} \\
\hline Undergraduate & 4,014 & $86 \%$ & $36 \%$ & TOTAL & 113 & 139 & & \\
\hline Graduate & 457 & $10 \%$ & $9 \%$ & Tenure \& Ten. Track & 83 & 1 & \multirow{2}{*}{$\begin{array}{l}\text { Community } \\
\text { Engagement: }\end{array}$} & \multirow{2}{*}{$\begin{array}{l}\text { Curricular Engagement and } \\
\text { Outreach and Partnerships }\end{array}$} \\
\hline Unclassified & 219 & $5 \%$ & $-4 \%$ & Non-Tenured Faculty & 30 & 138 & & \\
\hline
\end{tabular}

\section{DEGREE PRODUCTIVITY AND PROGRAM EFFICIENCY}

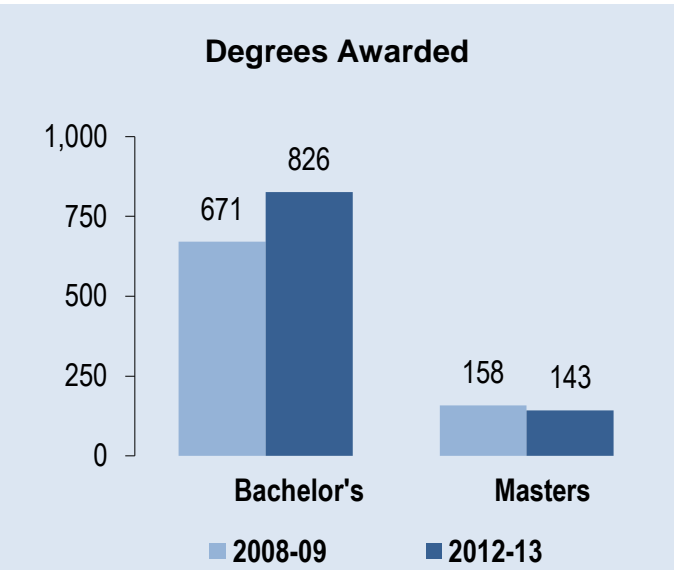

\section{Graduation Rates by Student Type}

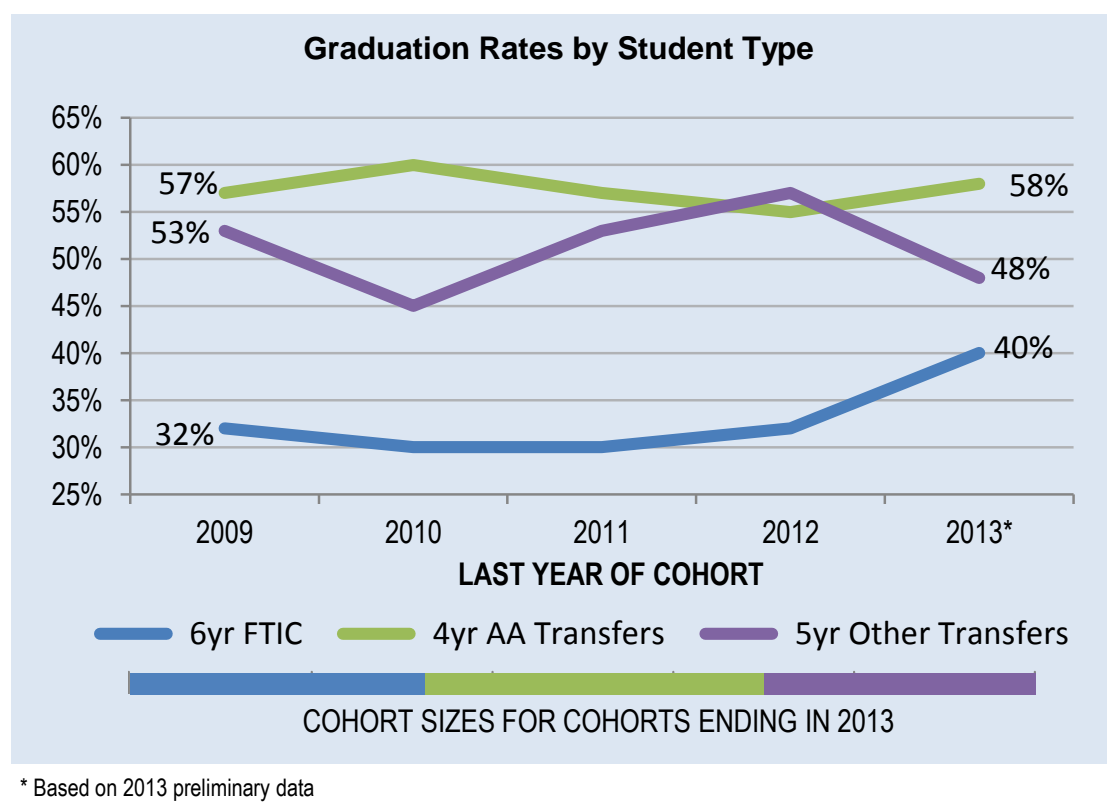

6yr FTIC $\rightleftharpoons$ 4yr AA Transfers $\rightleftharpoons$ yr Other Transfers

COHORT SIZES FOR COHORTS ENDING IN 2013

\section{Bachelor's Degrees by Group}

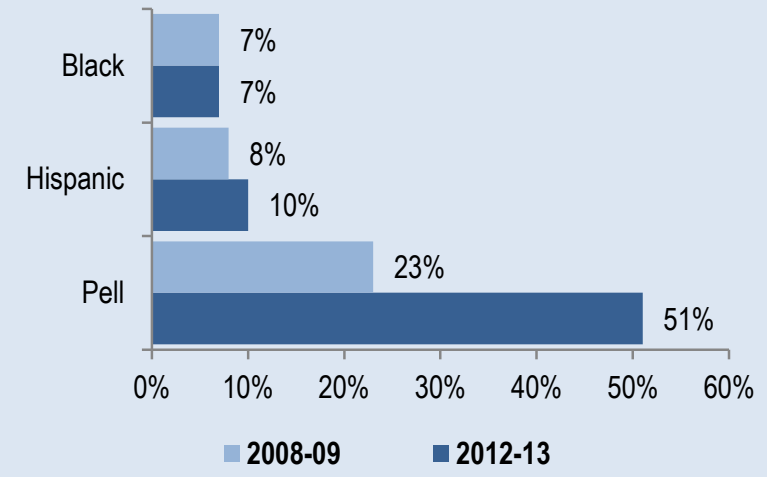

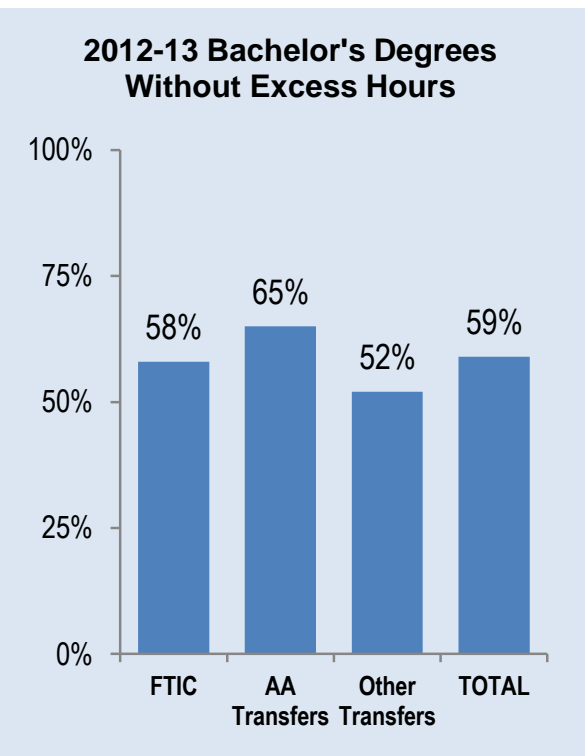




\section{Dashboard}

\section{DEGREES AWARDED IN PROGRAMS OF STRATEGIC EMPHASIS}
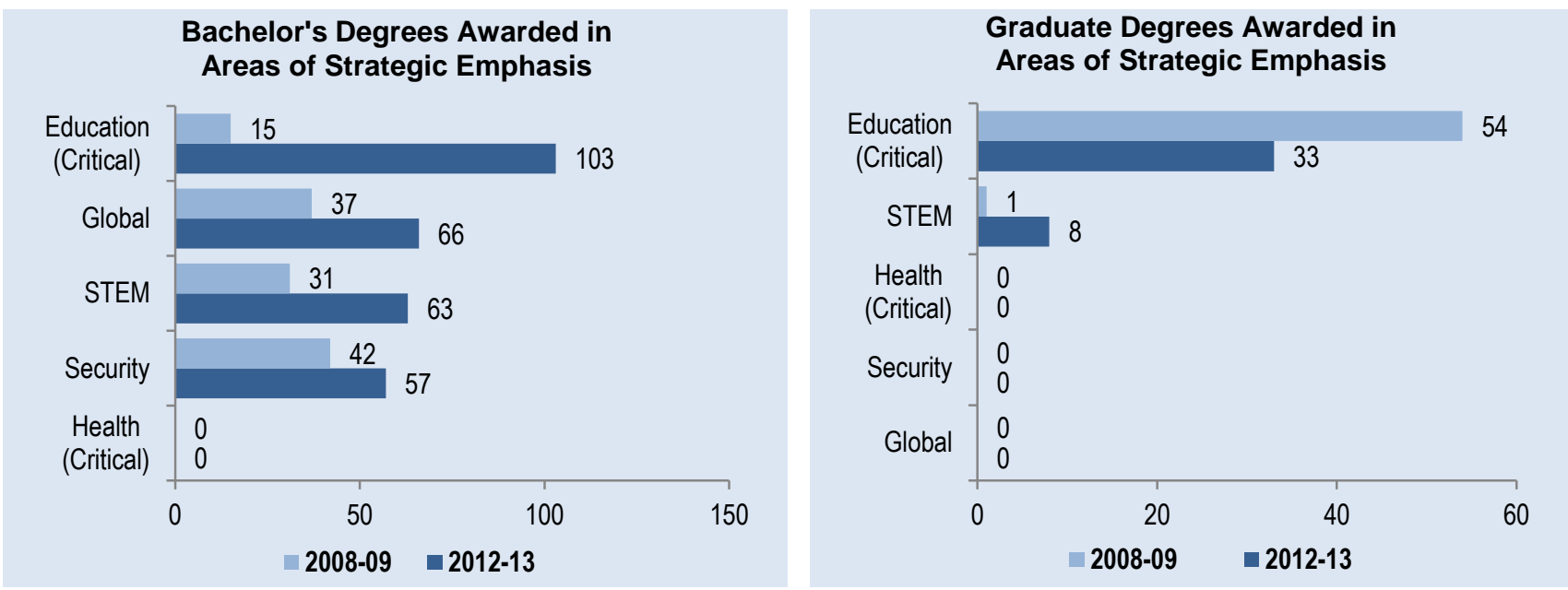

\section{RESEARCH AND COMMERCIALIZATION ACTIVITY}

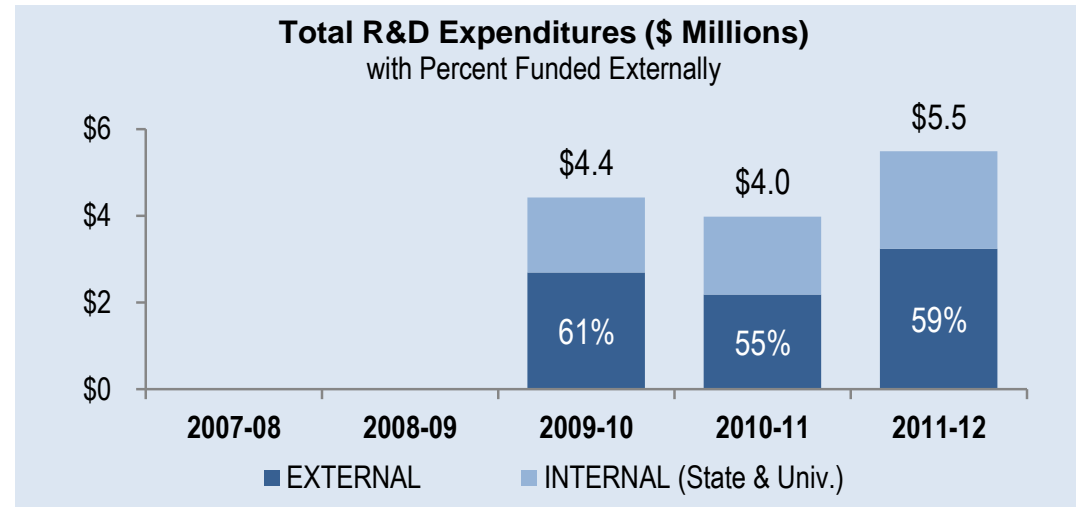

\section{RESOURCES}

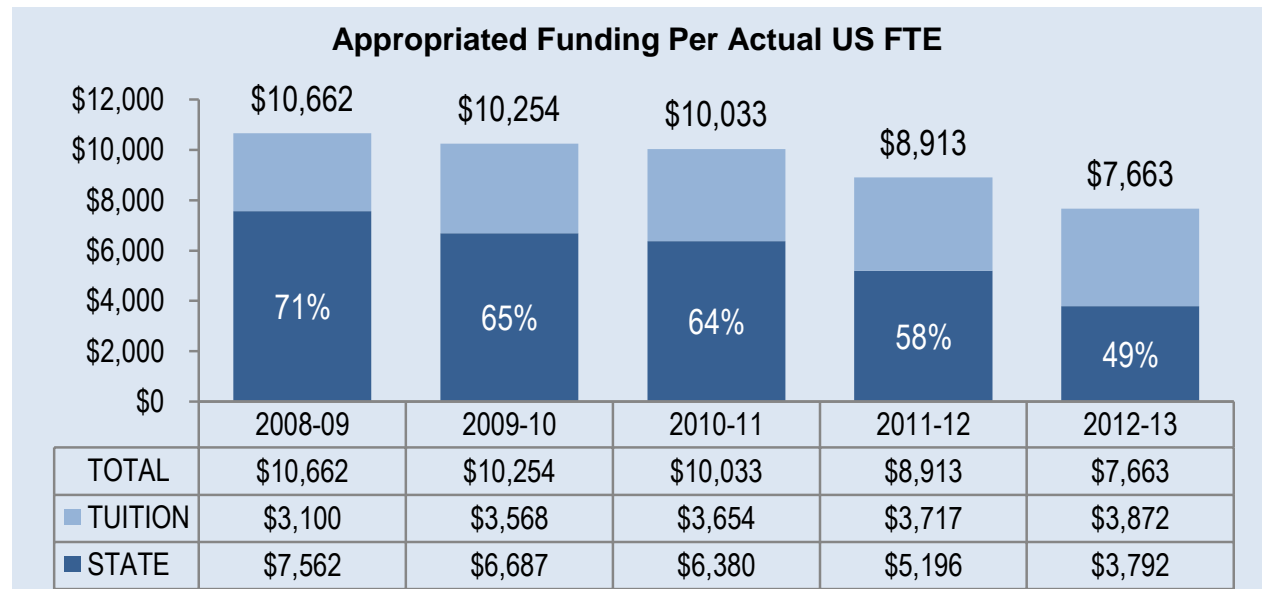

Note: Tuition is the appropriated budget authority, not the amount actually collected. This tuition data does not include noninstructional local fees. State includes General Revenues, Lottery and Other Trust funds (i.e., Federal Stimulus for 2009-10 and 2010-11 only). State funded financial aid programs that follow the student are included in tuition data. Student FTE are actual (not funded) and based on the national definition. 


\section{Dashboard}

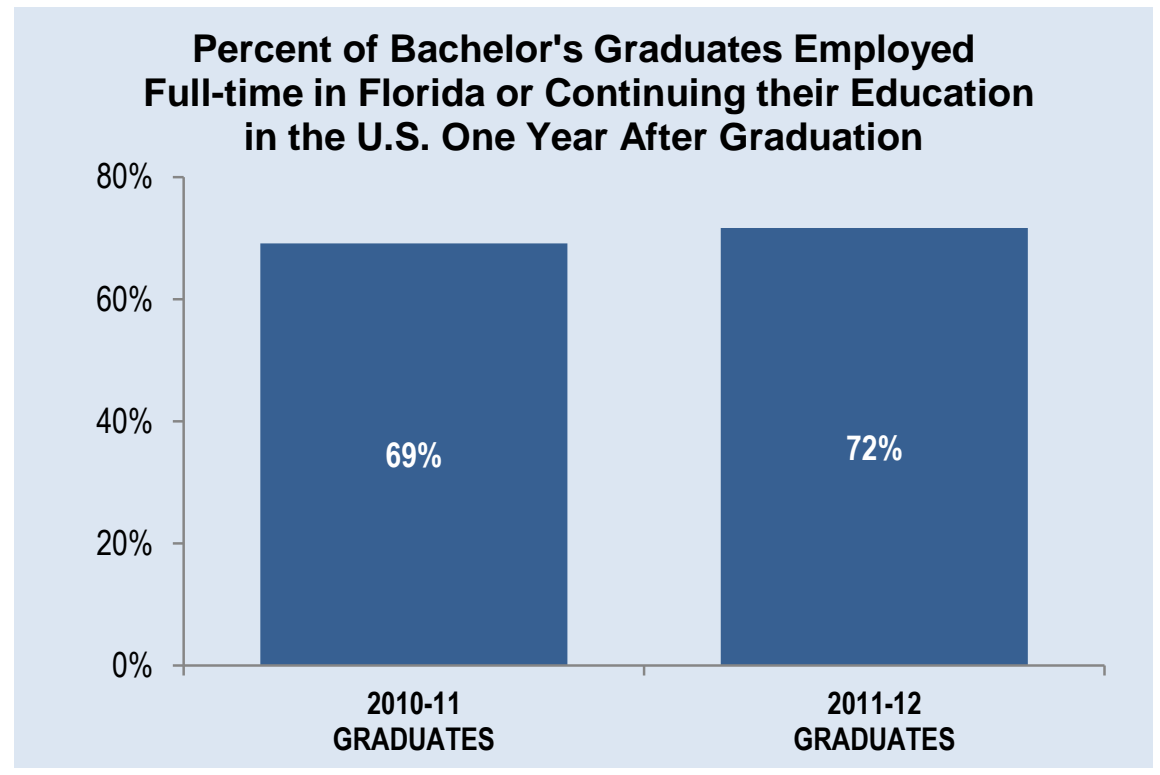

Wages of Full-time Employed in Florida Baccalaureates One Year After Graduation 25th, 50th and 75th Percentiles

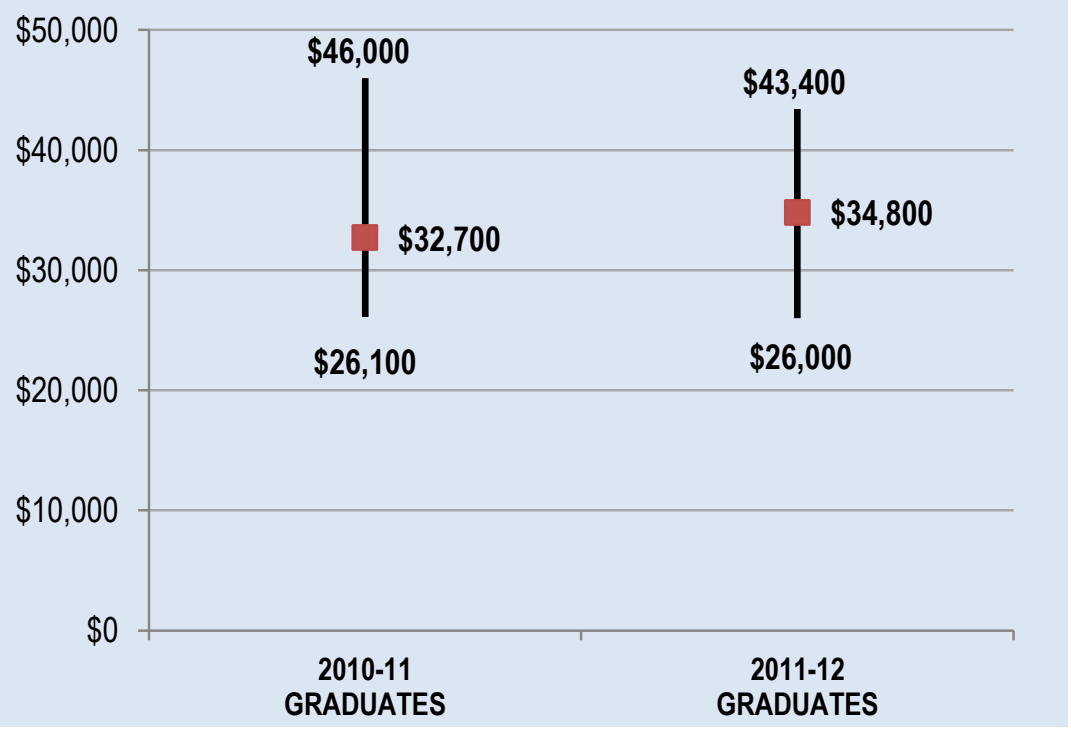

Notes: Percentages are based on the number of recent baccalaureate graduates who are either employed full-time in Florida (based on FETPIP data) or continuing their education in the U.S. (based on the National Student Clearinghouse data). Full-time employment is based on those who earned more than a full-time (40hrs a week) worker making minimum wage. Due to limitations in the data, the continuing enrollment data includes any enrollment the following year regardless of whether the enrollment was post-baccalaureate or not. These data account for $69 \%$ and $89 \%$ of the total graduating class for 2010-11 and 2011-12, respectively. BOG staff are actively working on adding non-Florida employment data to this measure for future reports.
Notes: Wage data is based on Florida's annualized Unemployment Insurance (UI) wage data for those graduates who earned more than a full-time employee making minimum wage in the fiscal quarter a full year after graduation. This wage data excludes graduates who were enrolled, regardless of their earnings. This UI wage data does not include individuals who are self-employed, employed out of state, employed by the military or federal government, or those without a valid social security number. These data account for $56 \%$ and $60 \%$ of the total graduating class for 2010-11 and 2011-12, respectively. Wages rounded to nearest hundreds. 


\section{Key Achievements (2012-2013)}

\section{STUDENT AWARDS/ACHIEVEMENTS}

1. Entrepreneurship students won the national Collegiate Entrepreneurs' Organization Startup Simulation Challenge for the second year in a row and garnered first- and third-place awards in the student pitch competition.

2. T. Hossain, Environmental Science, won an NSF Graduate Research Fellowship.

3. D. Ponticos, Florida Studies, and E. Southard, Anthropology, won Leland M. Hawes awards from the Tampa Bay History Center for the best research projects on Florida history.

4. S. Warner, Environmental Science and Policy, won the Outstanding Undergraduate Research Awards from the Florida Academy of Sciences.

5. L. Dellert, Biology undergraduate, was first author on a peer-reviewed publication in the Journal of Herpetology with Dr. Deby Cassill.

\section{FACULTY AWARDS/ACHIEVEMENTS}

1. Dr. T. Hallock was selected as the Daniel F. Breeden Eminent Scholar Chair for fall 2013 in the College of Liberal Arts at Auburn University.

2. Dr. S. Bundrick, awarded the Rome Prize, a fellowship to pursue advanced research at the American Academy in Rome.

3. Dr. H. Alegria, Associate Professor of Chemistry, was awarded fellowships in environmental chemistry by the Ministry of Education and Research of Estonia; and the Scientific and Technological Research Council of Turkey.

4. Dr. B. Dixon, Associate Professor of Geography, was elected President-Elect of the Florida Society of Geographers.

5. Dr. T. Whitmore, Assistant Professor of Biology, received the Outstanding Service Award at the International Paleolimnology Symposium Tiennial meetings, Glasgow, Scotland.

\section{PROGRAM AWARDS/ACHIEVEMENTS}

1. The Entrepreneurship Program in the College of Business was named the Outstanding Emerging Entrepreneurship Program in the nation by the U.S. Association for Small Business and Entrepreneurship.

2. The College of Business was reaccredited by AACSB International for both business and accounting, a double honor held by just 1 percent of business schools globally.

3. Beta Alpha Psi, the USFSP chapter of the national honor society in Accounting and Finance received superior recognition for the $6^{\text {th }}$ year in a row (since inception).

\section{RESEARCH AWARDS/ACHIEVEMENTS}

1. USFSP faculty garnered over $\$ 4$ million in external grant support in 2012-2013.

2. Dr. H. Merchant was ranked the 10th most prolific international management scholar in the world and the fourth most prolific scholar in the United States in a study published in Management International Review.

3. Dr. AnnMarie Gunn was awarded the American Educational Research Association's 2013 Dr. Carlos J. Vallejo Memorial Award for Emerging Scholarship.

\section{INSTITUTIONAL AWARDS/ACHIEVEMENTS}

1. USFSP was ranked 38th among the top regional public universities in the South by U.S. News \& World Report (2014 Edition). 


\section{Narrative}

\section{Teaching and Learning STRENGTHEN QUALITY AND REPUTATION OF ACADEMIC PROGRAMS AND UNIVERSITIES}

USFSP continues to strengthen the quality and reputation of its academic programs and the university. It was ranked 38th among the top regional public universities in the South by U.S. News \& World Report (2014 Edition). In 2012-2013, it established a chapter of Alpha Mu Gamma, the foreign language honor society, through the World Languages Program in the Department of Society, Culture, and Language, increasing to 10 the number of national honor societies on campus, serving majors in accounting, finance, business, economics, education, modern languages, journalism, criminology, psychology and English. Enrollment trends are consistent with these indicators of quality. In 2012-2013, USFSP enrolled 4,166 FTE students, which included 271 master's students, showing slight increases from the previous year.

The Entrepreneurship Program in the College of Business was named the Outstanding Emerging Entrepreneurship Program in the nation by the U.S. Association for Small Business and Entrepreneurship; and the College of Business was reaccredited by AACSB International for both business and accounting, a double honor held by just 1 percent of business schools globally. The College has a special focus on corporate and social responsibility, that is, the ethical and socially responsible conduct of business. USFSP graduates in both business and accounting are sought after by Florida firms since this ethos of corporate and social responsibility is highly valued and few institutions make it a focus of their programs.

To set the stage for a long future of high quality academic programs, particularly at the graduate level, as well as scholarly productivity and national recognition, USFSP added nine full-time faculty in the following key disciplines: Math and Science Education, Global Business, Accounting, Political Science, Graphic Design, French and Spanish, Environmental Science, and Psychology. These strategic hires were designed to facilitate the continued enhancement of the student experience through increased opportunities for faculty mentorship of student research, including graduate theses; increased engagement of faculty with the community; and increased student retention and degree completion.

Continuing its emphasis on quality academic programs, USFSP has begun conducting seven-year program reviews. Following recommendations from its program review, the faculty in Political Science moved aggressively to bolster its international focus through significant curricular revision and the addition of two key faculty hires: Assistant Professor Louis Mantilla, who specializes in Latin America and the Middle East; and Assistant Professor Ajay Verghese, specializing in the study of East Asia and Africa. As a result of the seven-year program review in English, the faculty revised its curriculum for the major. Two new streamlined tracks in the major, English Literature and Cultural Studies/Writing Studies, were implemented in the fall 2012 semester.

\section{INCREASE DEGREE PRODUCITIVITY AND PROGRAM EFFICIENCY}

Consistent with the 2013-2014 Work Plan, USFSP increased the percentage of residential students as a percentage of the total student body. USFSP opened 200 additional residential spaces in 2012, increasing the overall residential student numbers by 57 percent. Prior to 2012, USFSP housed about 13 percent of its undergraduate student body in university housing. National research shows that increased 
residential living promotes higher retention, greater student participation in co-curricular activities; and higher graduation rates.

To improve baccalaureate retention and graduation (USF System Goal 1); USFSP is assessing retention efforts institution-wide and developing a focused initiative for greater student retention and graduation. This will be a coordinated effort involving numerous constituencies and organizational units, including academic advising, tutoring services, wellness and counseling, admissions, residential life and education, student life and engagement, institutional effectiveness, and all academic units. In 2012-2013, USFSP retained its largest number of first year students ( $n=681$ compared to $n=576$ in 2011-2012). This represents a 76 percent first-year retention rate, comprising 74 percent of the students with a 2.0 GPA or higher. Although first-year retention continues to be positive, it represents a slight decrease from 20112012.

USFSP also focused on improving student outcomes in key mathematics courses through continued implementation of its Quality Enhancement Plan targeting quantitative literacy; a focus on improving access to academic support (i.e., tutoring); and a continued emphasis on strengthening academic advising. In fall 2012 the math recovery option was revised, originally designed to give students failing gateway mathematics courses a second chance to learn the material by retaking assessments on which they scored below 60 percent, to permit any student to retake an assessment before the next class assessment, earning the higher of the two scores with no penalty. As a direct result of student demand for recovery, the Math Recovery Center was created in fall 2012. Continued high demand for recovery led to the establishment of a permanent home for Math Recovery in BAY 227.

Results are highly encouraging. In 2012-13 48.6 percent of students earned grades of C- or higher for MAC 1105, College Algebra, when the QEP treatment of the Recovery Option is included. Without the QEP treatment included in grade computation, 28.7 percent of students would have earned grades of Cor higher. In 2012-13, only spring data is available for QEP for MGF 1106, Finite Mathematics. The course was redeveloped after the fall pilot. The text and online homework system Web Assign, in place in the fall, were unsatisfactory for a variety of reasons. The redesigned course was placed on MyMathLab, as suggested in the QEP. During the pilot on Web Assign I did not have access to other faculty grade records. In spring of 2013, 67.3 percent of students earned grades of C- or better for MGF 1106, Finite Mathematics, when the QEP treatment of the Recovery Option is included. Without the QEP treatment included in grade computation, 54.5 percent of students would have earned grades of C- or higher.

Baccalaureate graduation rates for fulltime students continue to show increases. Six-year baccalaureate graduation rates increased to 41 percent for the 2007-13 cohort, compared to previous cohorts beginning in 2003-2009 (32\%, 30\%, 30\%, 33\%, and 41\%). Four-year graduation rates show the same positive trend for the 2009-2013 cohort with a 23 percent graduation rate from USFSP (compared to 16 percent for the 2008-2012 cohort); and 36 percent graduation rate from the SUS System, (compared to 30 percent for the 2008-2012 cohort).

\section{INCREASE THE NUMBER OF DEGREES AWARDED IN S.T.E.M. AND OTHER PROGRAMS OF STRATEGIC EMPHASIS}

USFSP is committed to increasing the number of degrees awarded in STEM disciplines and other programs of strategic emphasis. In the fall of 2012, the College of Arts and Sciences launched a new B.S. in Biology. Interest in this newest degree has been very strong, attracting close to 450 majors in its inaugural year. Six of the first 12 students (50 percent) from the first Biological Sciences graduating class in spring 2013 were accepted into professional graduate programs (medical, dental, pharmaceutical). 
The language faculty in the College of Arts and Sciences developed a proposal for a new B.A. in Modern Language and Culture with a launch date of fall, 2013. With only one other degree of its type in the SUS inventory and a program of strategic emphasis for the BOG, we are excited about its prospects to expand interest and skill in languages, starting first with Spanish and French, but open to other possibilities as demand rises.

The fine art faculty in Graphic Design continues to advance a curricular and hiring plan to increase student capacity in the Bachelors of Fine Arts program which has traditionally been a limited access program with 20 students per entering fall class. Following a teach-out in the current cohort model, the new integrated model will be phased in to ensure greater access to this program of strategic emphasis.

The faculty in Environmental Science and Policy initiated a new minor in Geospatial Science, and modified the existing baccalaureate curriculum for its new highly anticipated concentration in Sustainability.

In addition, a new Health Science Scholarship was formed in spring of 2013 to support students in the new Health Science major, which enrolled 213 students in 2012-2013.

In fall of 2012, the College of Education began admitting students into its new master's degree in Middle Grades STEM. This program is uniquely designed to meet the critical content needs in mathematics and science of practicing middle school mathematics and science teachers.

In summer of 2013, the Study Abroad in Florida program, organized and coordinated by the Florida Institute of Oceanography (FIO) and hosted by the University of South Florida and USFSP biology faculty, took students on a tour of the state including stops at collaborative partners USF St. Petersburg, Florida Gulf Coast University in Ft. Myers, Florida Atlantic University (through the Keys Marine Lab), and the University of North Florida in Jacksonville to study marine ecosystems and marine biology.

All of these degree areas specifically address regional needs for professionals in a wide range of STEMrelated areas, as well as prepare students for success in doctoral programs in medicine and other health professions. In addition, the programs specifically address the areas of strategic emphasis in education, graphic design, and world languages. These programs have and will continue to produce graduates with the skills and knowledge to teach students depth of content in mathematics and science, to engage responsibly in sustainable science for economic competitiveness, and for graduates who can affect the health and progress of families, particularly those with very young children, in their community.

Baccalaureate degrees awarded in STEM increased significantly from 39 in 2011-2012 to 63 in $2012-$ 2013. Degrees awarded in programs of strategic emphases also increased. The combined categories of degrees awarded in STEM and programs of strategic emphases comprised 289 degrees awarded in 2012-2013, representing 34 percent of all degrees awarded. This represents a 38 percent increase from the previous year (i.e., 178 degrees awarded compared to 289). 


\section{Narrative}

\section{STRENGTHEN QUALITY AND REPUTATION OF SCHOLARSHIP, RESEARCH AND INNOVATION}

Many USFSP faculty have been recognized around the nation and the world as leading scholars in their fields:

- Florida Studies: Michael Francis was appointed as the first Hough Family Endowed Professor of Florida Studies. He was recognized by the Florida Humanities Council to lead historic tours to Spain focusing on Spanish explorers and early Florida.

- Dr. Chris Meindl was appointed the Frank E. Duckwall Professor of Florida Studies.

- Drs. Gary Mormino and Ray Arsenault, Professors of History, were co-recipients of the Dorothy Dodd Lifetime Achievement Award from the Florida Historical Society.

- The PBS Documentary, Freedom Riders, based on Ray Arsenault's award-winning book won a George Peabody Award for media excellence.

- In Biology, most upper-level courses require a research project. As such, 295 students taking biology courses completed original research posters. Each is in the process of writing a paper for submission to the USFSP Student Research Journal.

- Dr. Henry Alegria, Associate Professor of Chemistry, was awarded two important fellowships in his field of Environmental Chemistry: 1) The DoRa Fellowship by the Ministry of Education and Research of Estonia; 2) The Tubitak Visiting Research Fellowship by the Scientific and Technological Research Council of Turkey.

- Dr. Thomas Hallock, Assistant Professor of English, was selected as the Daniel F. Breeden Eminent Scholar Chair for fall 2013 in the College of Liberal Arts at Auburn University.

- Dr. Sheramy Bundrick, Assistant Professor of Art History, won the prestigious Rome Prize, a fellowship that will allow her to pursue advanced Research at the American Academy in Rome.

- The USF St. Petersburg Department of Journalism and Media Studies served as one of eight national hosts around the country for a week-long visit from 12 African journalists in the Edward R. Murrow. The program brings emerging journalism leaders from around the world to study journalistic practices in the United States in a public-private partnership involving the Department of State, the Aspen Institute and several prominent schools of journalism throughout the nation.

- Dr. Hemant Merchant, Professor of Management, was ranked the 10th most prolific international management scholar in the world and the fourth most prolific scholar in the United States in a study published in Management International Review.

- Dr. Martina Schmidt, Instructor in Finance, received the Best Teaching Innovation Award at the Annual Meeting of the National Academy of Business Disciplines.

- Dr. AnnMarie Gunn, Assistant Professor of Literacy and Reading, was awarded the American Educational Research Association's 2013 Dr. Carlos J. Vallejo Memorial Award for Emerging Scholarship.

\section{INCREASE RESEARCH AND COMMERCIALIZATION ACTIVITY}

Dr. Ray Arsenault, Professor of History, continues to explore opportunities to transform his history books into commercial feature films and documentaries. He was successful with the PBS film based on his book, Freedom Riders; with two books under option and a television mini-series in pre-production. 


\section{INCREASE COLLABORATION AND EXTERNAL SUPPORT FOR RESEARCH ACTIVITY}

The strategies for 2012-13 focused on increased research administration training for USFSP staff, faculty and students, increased identification of opportunities for external funding for scholarly activities and enhanced reporting of research funding, and enhanced support for student scholarship including offering free printing of research posters and support for student travel to professional meetings. The creation of a database for undergraduate and graduate student research activities was also implemented.

The results have been positive. In 2012-13, requests for external support for research increased more than 10 percent from the previous year to a record total of $\$ 16.7$ million. Of the 34 proposals, 15 awards were made totaling over $\$ 4$ million. Funding reports are now issued quarterly and reviewed by the USFSP Senior Leadership Group. USFSP faculty members continue to garner accolades for their work.

\section{Community and Business Engagement}

\section{STRENGTHEN QUALITY AND REPUTATION OF COMMITMENT TO COMMUNITY AND BUSINESS ENGAGEMENT}

As one of only 311 "Civically Engaged Universities," in the U.S., per its classification from the Carnegie Corporation, USFSP continued its tradition of meaningful engagement with the local community and businesses in 2012-2013.

In 2012-2013, 939 students at USFSP enrolled in 44 civic engagement courses through the USFSP Citizen Scholar Program out of the Wally and Louise Bishop Center for Ethical Leadership and Civic Engagement. In addition, almost 20 percent were identified as Citizen Scholar Courses and listed in the Citizen Scholar Course Catalog. More than 75 community partners were engaged in community partnerships with community organizations comprising county and city offices as well as non-profit agencies and organizations throughout Pinellas County. USFSP has identified 66 Citizen Scholar courses, 29 courses in the College of Education (66 percent), 13 courses in the College of Business (11 percent), and 24 courses in the College of Arts and Sciences (5 percent).

The Florida Studies program extended its collaborative relationships with several community organizations including the Carter G. Woodson African American Museum, the Studio@620, the St. Petersburg Museum of Fine Arts, the St. Petersburg Museum of History, and the African American Heritage Trail.

The history faculty has collaborated successfully with the staff of the Southern Historical Association to bring the Southern Historical Association Meeting to St. Pete Beach in 2016.

Faculty in the USFSP College of Business collaborated with the Clearwater Marine Aquarium (CMA) on a research study to estimate the economic impact of the film-induced tourism on the local ec o nom y generated by the movie Dolphin Tale, a Warner Bros./Alcon Entertainment film, based on a real-life dolphin, "Winter," who resides at CMA. The movie was produced at CMA during fall 2010 and premiered domestically in September 2011 at about 5,500 theaters nationwide. The results of the study were presented at a press conference on August 16, 2012, generating wide visibility in the local media not only for the film and CMA but also for the USFSP college of business. The study predicted an approximated economic impact of $\$ 580$ million on the local economy during 2013 , and results have been of great support to CMA infrastructure expansion plans, given the expected increase in attendance of around 50 percent during 2013-2014 with respect to an increase of already 30 percent since the premier of the movie. 
In 2012-2013, 20 different local/regional accounting and finance firms partnered with Beta Alpha Psi (BAP), the USFSP chapter of the national honor society in Accounting and Finance. The firms were engaged in either in a professional, service or social endeavor; BAP students presented "Careers in the Financial Profession" to more than 150 local high school juniors and seniors at two local Pinellas County high schools.

As part of the College of Education's community outreach with local schools, more than 40 students volunteered at Fairmount Park Elementary, one of Pinellas County Schools (PCS) low-performing schools. Other examples of partnership with the school included meetings to inform and invite Fairmount staff to join the USFSP graduate program as students; to connect USFSP staff with Fairmount management (in the PCS's Executive Partnership to Advance Student Success (PASS) program); and to assist Fairmount Park with their community outreach staffing needs and with possible grant funding activities with PCS.

2012 saw the development of a strategic partnership between USFSP and the Salvador Dali Museum. Numerous faculty members in the College of Education were involved in developing the partnership. For example, Dr. Cynthia Leung, Professor of Literacy and English Education, engaged her class of 25 master's students in English Education creating projects that connected writing and art in the school classroom, as a result of their immersion in sessions at the Dali Museum.

In summer of 2013, The Teacher Leaders Institute brought to campus more than 200 educators from Pinellas, Pasco, and Hillsborough counties for a two-day event. The program was designed for teachers committed to improving their leadership skills and equally committed to remaining in the classroom as teacher-leaders. Dr. Pedro Noguera, Peter L. Agnew Professor of Education, New York University, was the event's keynote speaker.

The USFSP Honors Program created a community advisory board; its membership will provide mentoring and career awareness to our students. The Honors Program also created the "St. Petersburg in the World Honors Program," to engage retired members of the US diplomatic core with our students on a range of topics in political science. The program hosted several public fora during 2012-2013.

\section{INCREASE LEVELS OF COMMUNITY AND BUSINESS ENGAGEMENT}

Faculty in Environmental Science hosted a successful on-campus GIS Day in collaboration with many local business organizations including Spatial Networks Inc., Valpak, Chenega Global, WeoGeo as well as Government organizations such as USGS, NOAA, FWC, and Hillsborough Environmental Commission.

Faculty in Environmental Science and Policy provided a series of GIS Workshops for local business organizations (i.e. Stantec, Renaissance Planning Group, CF Industries, and Val Pak) and from area NGO's, local, state and federal Governments including Hillsborough County, Florida Dept. of Transportation, US SOCOM, FWC, NOAA and USGS.

For the past six years the USFSP Program of Accountancy has offered a 3-credit course, both at the undergraduate and graduate levels that provides a tax internship for students who work in the IRS Volunteer Income Tax Assistance (VITA) program. This program focuses on helping low and moderate income taxpayers file tax returns and otherwise meet their obligations with the IRS. Twenty interns participated in the spring semester of 2013. Eleven of those were undergraduates and nine were graduate students. 
The Neighborhood News Bureau (NNB), a working newsroom that focuses on coverage in the Midtown area of St. Petersburg, is staffed by undergraduate and graduate students in the USFSP Program of Journalism and Media Studies. In addition to providing training for USFSP students, it functions as a community connection for collecting and disseminating information and news for local, regional, and community publications. Twenty-three USFSP students participated in the NNB in 2012-2013.

\section{INCREASE COMIMUNITY AND BUSINESS WORKFORCE}

Faculty in the Program of Entrepreneurship presented creative thinking and economic and workforce development ideas for the Pasco County regional planning meeting.

Faculty in Environmental Science worked closely with Pinellas County Worknet (Pinellas Worknet) to offer GIS Workshops and assisted the Polk County Election Commission with their redistricting projects.

Students with advanced GIS training from USFSP were placed as interns with various subcontractors to USSOCOM including GEOEYE, IAP worldwide, as well as local businesses such as Valpak, and Impetus Research, Inc.

Marketing students in the class "Marketing Strategy and Marketing Management Problems" worked with local community businesses and nonprofits to develop marketing plans. Local clients included: Swearingen \& Kelli, a St. Petersburg-based folk-rock group; the Bishop Center for Ethical Leadership and Civic Engagement; Daystar Life Center, an organization assisting needy individuals with basic necessities; American Stage Theatre; the USFSP College of Education; Inner Calm Communications, a Tampa-based holistic healer; the USFSP Waterfront; Cerulean Blu Swimwear, a St. Petersburg women's fashion retailer; and Suncoast Dance and Music Studio.

The College of Education initiated practicum opportunities for its students at the Arista Café at Mercedes Benz in Tampa working with students with autism who are employed as coffee shop employees.

The USFSP Biology major was created in response to the expressed needs of the local health care facilities and professionals in our city and region. Its students are engaged in internships throughout the region's health care industry. 


\section{Data Tables}

\section{FINANCIAL RESOURCES}

Table 1A. Education and General Revenues

Table 1B. Education and General Expenditures

Table 1C. Funding per Student FTE

Table 1D. Other Budget Entities

Table 1E. Voluntary Support of Higher Education

Table 1F. Tuition Differential Fee

PERSONNEL

Table 2A. Personnel Headcount

\section{ENROLLMENT}

Table 3A. Full-time Equivalent (FTE) Enrollment

Table 3C. Enrollment by Method of Instruction

\section{UNDERGRADUATE EDUCATION}

Table 4A. Baccalaureate Degree Program Changes in AY 2011-2012

Table 4B. Retention Rates

Table 4C. Full-time, First-Time-in-College (FTIC) Six-Year Graduation Rates

Table 4D. Full- and Part-time FTIC Graduation Rates

Table 4E. AA Transfers Graduation Rates

Table 4F. Other Transfers Graduation Rates

Table 4G. Baccalaureate Degrees Awarded

Table 4H. Baccalaureate Degrees Awarded in Areas of Strategic Emphasis

Table 4I. Baccalaureate Degrees Awarded to Underrepresented Groups

Table 4J. Baccalaureate Degrees Without Excess Credit Hours

Table 4K. Undergraduate Course Offerings

Table 4L. Faculty Teaching Undergraduates

Table 4M. Student/Faculty Ratio

Table 4N. Licensure/Certification Exam: Nursing (NCLEX)

\section{GRADUATE EDUCATION}

Table 5A. Graduate Degree Program Changes in AY 2011-2012

Table 5B. Graduate Degrees Awarded

Table 5C. Graduate Degrees Awarded in Areas of Strategic Emphasis

Table 5D. Licensure/Certification Exams for Graduate Programs

\section{RESEARCH \& ECONOMIC DEVELOPMENT}

Table 6A. Research and Development Expenditures

Table 6B. Centers of Excellence 
Section 1 - Financial Resources TABLE 1A. University Education and General Revenues

\begin{tabular}{|c|c|c|c|c|c|}
\hline & $\begin{array}{c}2009-10 \\
\text { Actual }\end{array}$ & $\begin{array}{c}2010-11 \\
\text { Actual }\end{array}$ & $\begin{array}{c}2011-12 \\
\text { Actual } \\
\end{array}$ & $\begin{array}{c}2012-13 \\
\text { Actual }\end{array}$ & $\begin{array}{c}2013-14 \\
\text { Estimates }\end{array}$ \\
\hline \multicolumn{6}{|l|}{ MAIN OPERATIONS } \\
\hline Recurring State Funds & $\$ 22,545,822$ & $\$ 22,330,354$ & $\$ 21,161,442$ & $\$ 21,974,862$ & $\$ 22,196,555$ \\
\hline Non-Recurring State Funds & $\$ 162,435$ & $\$ 177,904$ & $\$ 241,627$ & $-\$ 5,111,531$ & $\$ 131,000$ \\
\hline Tuition & $\$ 12,477,913$ & $\$ 13,673,156$ & $\$ 15,649,557$ & $\$ 17,204,867$ & $\$ 21,417,775$ \\
\hline Tuition Differential Fee & $\$ 409,066$ & $\$ 1,046,262$ & $\$ 1,965,224$ & $\$ 3,438,880$ & $\$ 4,533,845$ \\
\hline Misc. Fees \& Fines & $\$ 256,990$ & $\$ 198,148$ & $\$ 214,107$ & $\$ 180,959$ & $\$ 265,191$ \\
\hline Phosphate Research TF & $\$ 0$ & $\$ 0$ & $\$ 0$ & $\$ 0$ & $\$ 0$ \\
\hline Federal Stimulus Funds & $\$ 1,925,121$ & $\$ 1,842,058$ & $\$ 0$ & $\$ 0$ & $\$ 0$ \\
\hline SUBTOTAL & $\$ 37,777,347$ & $\$ 39,267,882$ & $\$ 39,231,957$ & $\$ 37,688,037$ & $\$ 48,544,366$ \\
\hline \multicolumn{6}{|c|}{ HEALTH SCIENCE CENTER / MEDICAL SCHOOL } \\
\hline SUBTOTAL & $\$ 0$ & $\$ 0$ & $\$ 0$ & $\$ 0$ & $\$ 0$ \\
\hline TOTAL & $\$ 37,777,347$ & $\$ 39,267,882$ & $\$ 39,231,957$ & $\$ 37,688,037$ & $\$ 48,544,366$ \\
\hline
\end{tabular}

Recurring State Funds: State recurring funds include general revenue and lottery education \& general (E\&G) appropriations and any administered funds provided by the state, including annual adjustments of risk management insurance premiums for the estimated year. This does not include technical adjustments or transfers made by universities after the appropriation. Please note: for estimated 2012-13 this figure includes the non-recurring $\$ 300 \mathrm{M}$ system budget reduction. - Source: For actual years, SUS Final Amendment Packages; for estimated year the 2012-13 Allocation Summary and Workpapers (Total E\&G general revenue \& lottery minus non-recurring) and Board of Governors staff calculations for risk management insurance adjustments. Non-Recurring State Funds: State non-recurring funds include general revenue and lottery education \& general appropriations and any administered funds provided by the state. This does not include technical adjustments or transfers made by Universities after the appropriation - Source: non-recurring appropriations section of the annual Allocation Summary and Workpapers document and all other non-recurring budget amendments allocated later in the fiscal year. Tuition: Actual resident \& nonresident tuition revenues collected from students, net of fee waivers. - Source: Operating Budget, Report 625 - Schedule I-A. Tuition Differential Fee: Actual tuition differential revenues collected from undergraduate students - Source: Operating Budget, Report 625 - Schedule I-A. Miscellaneous Fees \& Fines: Other revenue collections include items such as application fees, late registration fees, library fines, miscellaneous revenues. This is the total revenue from Report 625 minus tuition and tuition differential fee revenues. This does not include local fees - Source: Operating Budget, Report 625 - Schedule I-A. Phosphate Research Trust Fund: State appropriation for the Florida Industrial and Phosphate Research Institute at the University of South Florida (for history years through 2011-12); beginning 2012-13 the Phosphate Research Trust Fund is appropriated through Florida Polytechnic University. Other Operating Trust Funds- For UF-IFAS and UF-HSC, actual revenues from the Incidental Trust Funds and Operations \& Maintenance Trust Fund are provided by the University of Florida. Source: Final Amendment Package. Federal Stimulus Funds: Non-recurring American Recovery and Reinvestment Act funds appropriated by the state Source: SUS Final Amendment Package. 
Section 1 - Financial Resources (continued) TABLE 1B. University Education and General Expenditures

\begin{tabular}{|c|c|c|c|c|c|}
\hline & $\begin{array}{c}2009-10 \\
\text { Actual }\end{array}$ & $\begin{array}{c}2010-11 \\
\text { Actual }\end{array}$ & $\begin{array}{c}2011-12 \\
\text { Actual }\end{array}$ & $\begin{array}{l}2012-13 \\
\text { Actual }^{*}\end{array}$ & $\begin{array}{c}\text { 2013-14 } \\
\text { Estimates }\end{array}$ \\
\hline \multicolumn{6}{|l|}{ MAIN OPERATIONS } \\
\hline Instruction/Research & $\$ 20,220,884$ & $\$ 21,123,344$ & $\$ 21,200,464$ & $\$ 24,698,212$ & $\$ 36,346,895$ \\
\hline Administration and Support & $\$ 3,313,581$ & $\$ 3,366,169$ & $\$ 2,653,731$ & $\$ 4,811,738$ & $\$ 3,703,230$ \\
\hline PO\&M & $\$ 4,239,436$ & $\$ 3,574,046$ & $\$ 3,690,915$ & $\$ 4,036,733$ & $\$ 5,241,751$ \\
\hline Student Services & $\$ 1,418,035$ & $\$ 1,424,880$ & $\$ 1,510,047$ & $\$ 1,958,948$ & $\$ 1,981,913$ \\
\hline Library/Audio Visual & $\$ 1,252,316$ & $\$ 1,427,612$ & $\$ 1,449,515$ & $\$ 1,422,051$ & $\$ 1,269,974$ \\
\hline Other & $\$ 0$ & $\$ 0$ & $\$ 0$ & $\$ 0$ & $\$ 0$ \\
\hline TOTAL & $\$ 30,444,252$ & $\$ 30,916,051$ & $\$ 30,504,672$ & $\$ 36,927,682$ & $\$ 48,543,763$ \\
\hline
\end{tabular}

HEALTH SCIENCE CENTER / MEDICAL SCHOOL

\begin{tabular}{llllll}
\hline TOTAL & $\$ 0$ & $\$ 0$ & $\$ 0$ & $\$ 0$ & $\$ 0$
\end{tabular}

TOTAL

\section{$\$ 30,444,252 \quad \$ 30,916,051 \quad \$ 30,504,672 \quad \$ 36,927,682 \quad \$ 48,543,763$}

The table reports the actual and estimated amount of expenditures from revenues appropriated by the legislature for each fiscal year. The expenditures are classified by Program Component (i.e., Instruction/Research, PO\&M, Administration, etc...) for activities directly related to instruction, research and public service. The table does not include expenditures classified as non-operating expenditures (i.e., to service assetrelated debts), and therefore excludes a small portion of the amount appropriated each year by the legislature. Note*: FY 2012-2013 reflects a change in reporting expenditures from prior years due to the new carry-forward reporting requirement as reflected in the 2013-2014 SUS Operating Budget Reports. Since these expenditures will now include carry-forward expenditures, these data are no longer comparable to the current-year revenues reported in table 1A. Note ${ }^{* *}$. Estimated year amounts are from FY 2013-14 appropriations only and do not include anticipated expenditures from university carry-forward funds.

Instruction \& Research: Includes expenditures for state services related to the instructional delivery system for advanced and professional education. Includes functions such as; all activities related to credit instruction that may be applied toward a postsecondary degree or certificate; nonproject research and service performed to maintain professional effectives; individual or project research; academic computing support; academic source or curriculum development. Source: Operating Budget Summary - Expenditures by Program Activity (or Report 645). Administration \& Support Services: Expenditures related to the executive direction and leadership for university operations and those internal management services which assist and support the delivery of academic programs. Source: Operating Budget Summary - Expenditures by Program Activity (or Report 645). PO\&M: Plant Operations \& Maintenance expenditures related to the cleaning and maintenance of existing grounds, the providing of utility services, and the planning and design of future plant expansion and modification. Student Services: Includes resources related to physical, psychological, and social well being of the student. Includes student service administration, social and cultural development, counseling and career guidance, financial aid, and student admissions and records. Other: includes Institutes and Research Centers, Radio/TV, Museums and Galleries, Intercollegiate Athletics, Academic Infrastructure Support Organizations. Source: Operating Budget Summary - Expenditures by Program Activity (or Report 645). 
Section 1 - Financial Resources (continued) TABLE 1C. State Funding per Full-Time Equivalent (FTE) Student (Data Provided by USF)

\begin{tabular}{lrrrrr} 
& $\begin{array}{c}\mathbf{2 0 0 8 - 0 9} \\
\text { Actual }\end{array}$ & $\begin{array}{r}\mathbf{2 0 0 9 - 1 0} \\
\text { Actual }\end{array}$ & $\begin{array}{r}\mathbf{2 0 1 0 - 1 1} \\
\text { Actual }\end{array}$ & $\begin{array}{r}\mathbf{2 0 1 1 - 1 2} \\
\text { Actual }\end{array}$ & $\begin{array}{r}\text { 2012-13 } \\
\text { Actual }\end{array}$ \\
\hline Appropriated Funding per FTE & & & & & \\
\hline General Revenue & $\$ 7,219$ & $\$ 5,926$ & $\$ 5,570$ & $\$ 4,821$ & $\$ 3,546$ \\
Lottery Funds & $\$ 343$ & $\$ 238$ & $\$ 327$ & $\$ 375$ & $\$ 246$ \\
Tuition \& Fees & $\$ 3,100$ & $\$ 3,568$ & $\$ 3,654$ & $\$ 3,717$ & $\$ 3,872$ \\
Other Trust Funds & $\$ 0$ & $\$ 523$ & $\$ 483$ & $\$ 0$ & $\$ 0$ \\
TOTAL & $\$ 10,662$ & $\$ 10,254$ & $\$ 10,033$ & $\$ 8,913$ & $\$ 7,663$
\end{tabular}

\section{Actual Funding per FTE}

\begin{tabular}{|c|c|c|c|c|}
\hline Tuition \& Fees & $\$ 3,100$ & $\$ 3,568$ & $\$ 3,908$ & $\$ 4,328$ \\
\hline TOTAL & $\$ 10,662$ & $\$ 10,255$ & $\$ 10,288$ & $\$ 9,525$ \\
\hline
\end{tabular}

Notes: (1) FTE is based on actual FTE, not funded FTE; (2) does not include Health-Science Center funds or FTE; (3) FTE for these metrics uses the standard IPEDS definition of FTE, equal to 30 credit hours for undergraduates and 24 for graduates; and (4) actual funding per student is based on actual tuition and E\&G fees (does not include local fees) collected. Sources: Appropriated totals from the annual Final Amendment Package data. Estimated year data from the Allocation Summary document. Actual Student Fees from the Operating Budget 625 reports. This does not include appropriations for special units (i.e., IFAS, Health Science Centers, and Medical Schools). Tuition and fee revenues include tuition and tuition differential fee and E\&G fees (i.e., application, late registration, and library fees/fines). Other local fees that do not support E\&G activities are not included here (see Board of Governors Regulation 7.003). This data is not adjusted for inflation.

TABLE 1D. University Other Budget Entities

$\begin{array}{cc}2009-10 & 2010-11 \\ \text { Actual } & \text { Actual }\end{array}$

2011-12 Actual
2012-13 Actual
2013-14

Estimates

\section{Auxiliary Enterprises}

Revenues

Expenditures

\section{Contracts \& Grants}

Revenues

Expenditures
Previously reported only

at the USF System level.

\section{$\$ 8,207,956$}

$\$ 4,596,917$
$\$ 12,298,149$

$\$ 8,347,332$
$\$ 12,965,879$

$\$ 13,054,899$

\section{Local Funds}

$\begin{array}{lllll}\text { Revenues } & \text { Previously reported only } & \$ 3,875,688 & \$ 4,117,824 & \$ 4,372,905 \\ \text { Expenditures } & \text { at the USF System level. } & \$ 1,832,342 & \$ 2,743,811 & \$ 4,968,943\end{array}$

\section{Faculty Practice Plans}

$\begin{array}{lllll}\text { Revenues } & \text { Previously reported only } & \$ 0 & \$ 0 & \$ 0 \\ \text { Expenditures } & \text { at the USF System level. } & \$ 0 & \$ 0 & \$ 0\end{array}$

Notes: Revenues do not include transfers. Expenditures do not include non-operating expenditures. Auxiliary Enterprises are self supported through fees, payments and charges. Examples include housing, food services, bookstores, parking services, health centers. Contract \& Grants resources are received from federal, state or private sources for the purposes of conducting research and public service activities. Local Funds are associated with student activity (supported by the student activity fee), student financial aid, concessions, intercollegiate athletics, technology fee, green fee, and student life \& services fee. Faculty Practice Plan revenues/receipts are funds generated from faculty practice plan activities. Faculty Practice Plan expenditures include all expenditures relating to the faculty practice plans, including transfers between other funds and/or entities. This may result in double counting in information presented within the annual report. Source: Operating Budget, Report 615. 
Section 1 - Financial Resources (continued) TABLE 1E. Voluntary Support of Higher Education

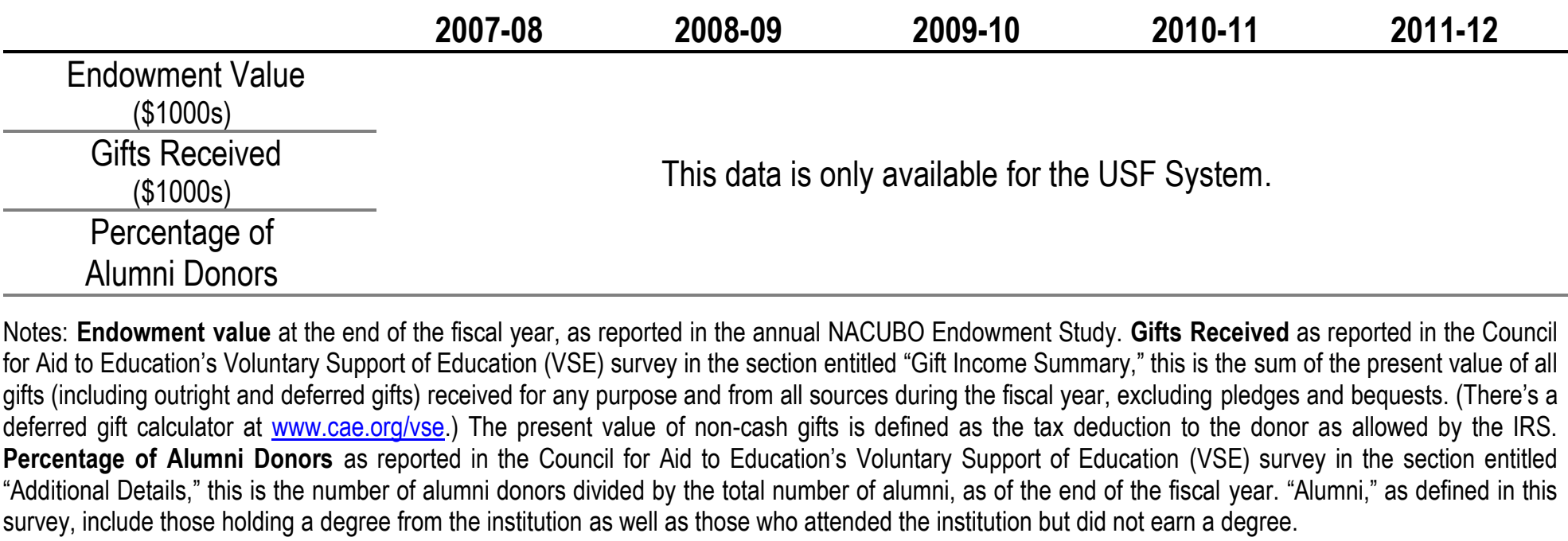

\section{TABLE 1F. Tuition Differential Fees (TDF)}

\begin{tabular}{lccc} 
& $\mathbf{2 0 1 0 - 1 1}$ & $\mathbf{2 0 1 1 - 1 2}$ & $\mathbf{2 0 1 2 - 1 3}$ \\
\hline TDF Revenues Generated & $\$ 1,046,262$ & $\$ 1,965,224$ & $\$ 3,438,880$ \\
\hline Students Receiving TDF Funded Award & 281 & 476 & 881 \\
Total Value of TDF Funded Financial Aid Awards & $\$ 1,118$ & $\$ 1,239$ & $\$ 1,068,738$
\end{tabular}

\section{Florida Student Assistance Grant (FSAG) Eligible Students}

\begin{tabular}{lccc}
\hline Number of Eligible Students & 593 & 660 & 1,166 \\
Number Receiving a TDF Waiver & 0 & 0 & 0 \\
Total Value of TDF Waivers & $\$ 0$ & $\$ 0$ & $\$ 0$
\end{tabular}

Note: TDF Revenues Generated refers to actual tuition differential revenues collected from undergraduate students as reported on the Operating Budget, Report 625 - Schedule I-A. Students Receiving TDF Funded Award reports the number of unduplicated students who have received a financial aid award that was funded by tuition differential revenues. Value of TDF Funded Award refers to the average value of financial aid awards funded by the the Tuition Differential Fee funds. Florida Student Assistance Grant (FSAG) Eligible Students: Number of Eligible Students refers to total annual unduplicated count of undergraduates at the institution who are eligible for FSAG in the academic year, whether or not they received FSAG awards. Number Receiving a TDF Waiver refers to annual unduplicated count of FSAG-eligible students receiving a waiver, partial or full, of the tuition differential fees at the institution during the academic year, regardless of the reason for the waiver. Value of TDF Waivers refers to the average value of waivers provided to FSAG-eligible undergraduates at the institution during the academic year, regardless of the reason for the waiver. 


\section{Section 2 - Personnel}

\section{TABLE 2A. Personnel Headcount (in Fall term only)}

\begin{tabular}{lccccc} 
& $\mathbf{2 0 0 8}$ & $\mathbf{2 0 0 9}$ & $\mathbf{2 0 1 0}$ & $\mathbf{2 0 1 1}$ & $\mathbf{2 0 1 2}$ \\
\hline Full-time Employees & 50 & 53 & 56 & 58 & 58 \\
Tenured Faculty & 37 & 32 & 24 & 25 & 25 \\
Tenure-track Faculty & 26 & 27 & 27 & 24 & 30 \\
Non-Tenure Track Faculty & 0 & 0 & 0 & 0 & 0 \\
Instructors Without Faculty Status & 0 & 0 & 0 & 0 & 0 \\
Graduate Assistants/Associates & 197 & 193 & 194 & 208 & 224 \\
Non-Instructional Employees & $\mathbf{3 1 0}$ & $\mathbf{3 0 5}$ & $\mathbf{3 0 0}$ & $\mathbf{3 1 5}$ & $\mathbf{3 3 7}$ \\
FULL-TIME SUBTOTAL & & & & & \\
Part-time Employees & 0 & 0 & 0 & 1 & 1 \\
Tenured Faculty & 1 & 0 & 0 & 2 & 0 \\
Tenure-track Faculty & 8 & 9 & 8 & 116 & 138 \\
Non-Tenure Track Faculty & 0 & 0 & 0 & 0 & 0 \\
Instructors Without Faculty Status & 20 & 26 & 33 & 28 & 31 \\
Graduate Assistants/Associates & 153 & 154 & 175 & 2 & 0 \\
Non-Instructional Employees & $\mathbf{1 8 2}$ & $\mathbf{1 8 9}$ & $\mathbf{2 1 6}$ & $\mathbf{1 4 9}$ & $\mathbf{1 7 0}$ \\
\hline PART-TIME SUBTOTAL & $\mathbf{4 9 2}$ & $\mathbf{4 9 4}$ & $\mathbf{5 1 6}$ & $\mathbf{4 6 4}$ & $\mathbf{5 0 7}$ \\
\hline \multicolumn{1}{c}{ TOTAL } & & & & &
\end{tabular}

Note: This table is based on the annual IPEDS Human Resources Survey, and provides full- and part-time medical and non-medical staff by faculty status and primary function/occupational activity. Tenured and Tenure-Track Faculty include those categorized within instruction, research, or public service. Non-Tenure Track Faculty includes adjunct faculty (on annual and less than annual contracts) and faculty on multi-year contracts categorized within instruction, research, or public service. Instructors Without Faculty Status includes postdoctoral research associates, and individuals hired as a staff member primarily to do research on a 3-year contract without tenure eligibility categorized within instruction, research, or public service. Non-Instructional Employees includes all executive, administrative and managerial positions regardless of faculty status; as well as, other support and service positions regardless of faculty status. Note: The universities vary on how they classify adjuncts (some include them as non-tenure track faculty while others do not consider them faculty and report them as instructors without faculty status) and part-time non-instructional employees. 


\section{Section 3 - Enrollment}

\section{TABLE 3A. Full-Time Equivalent (FTE) Enrollment}

\begin{tabular}{|c|c|c|c|c|c|c|}
\hline & \multicolumn{2}{|c|}{ 2010-11 } & \multicolumn{2}{|c|}{ 2011-12 } & \multicolumn{2}{|c|}{ 2012-13 } \\
\hline & $\begin{array}{l}\text { State- } \\
\text { Funded }\end{array}$ & Actual & $\begin{array}{l}\text { State- } \\
\text { Funded }\end{array}$ & Actual & $\begin{array}{l}\text { State- } \\
\text { Funded }\end{array}$ & Actual \\
\hline \multicolumn{7}{|c|}{ FLORIDA RESIDENTS } \\
\hline LOWER-DIVISION & 657 & 918 & 657 & 1,056 & 657 & 1,059 \\
\hline UPPER-DIVISION & 1,486 & 1,625 & 1,486 & 1,694 & 1,486 & 1,766 \\
\hline MASTER'S (GRAD I) & 227 & 251 & 227 & 259 & 227 & 281 \\
\hline DOCTORAL (GRAD II) & 0 & 1 & 0 & 1 & 0 & 28 \\
\hline TOTAL & 2,370 & 2,795 & 2,370 & 3,010 & 2,370 & 3,234 \\
\hline
\end{tabular}

\section{NON-FLORIDA RESIDENTS}

\begin{tabular}{lcc|cc|cc}
\hline LOWER-DIVISION & 0 & 29 & 0 & 33 & 0 & 36 \\
UPPER-DIVISION & 0 & 37 & 0 & 39 & 0 & 39 \\
MASTER'S (GRAD I) & 0 & 9 & 0 & 7 & 0 & 17 \\
DOCTORAL (GRAD II) & 0 & 0 & 0 & 0 & 0 & 0 \\
\hline TOTAL & $\mathbf{0}$ & $\mathbf{7 5}$ & $\mathbf{0}$ & $\mathbf{7 9}$ & $\mathbf{0}$ & $\mathbf{1 0 2}$
\end{tabular}

TOTAL FTE

\begin{tabular}{lcc|cc|cc}
\hline LOWER-DIVISION & 657 & 947 & 657 & 1,089 & 657 & 1,195 \\
UPPER-DIVISION & 1,486 & 1,662 & 1,486 & 1,733 & 1,486 & 1,805 \\
MASTER'S (GRAD I) & 227 & 260 & 227 & 266 & 227 & 298 \\
DOCTORAL (GRAD II) & 0 & 1 & 0 & 1 & 0 & 38 \\
\hline TOTAL & $\mathbf{2 , 3 7 0}$ & $\mathbf{2 , 8 7 0}$ & $\mathbf{2 , 3 7 0}$ & $\mathbf{3 , 0 8 9}$ & $\mathbf{2 , 3 7 0}$ & $\mathbf{3 , 3 3 6}$ \\
\hline TOTAL & $\mathbf{3 , 1 5 2}$ & $\mathbf{3 , 8 2 7}$ & $\mathbf{3 , 1 6 0}$ & $\mathbf{4 , 1 1 9}$ & $\mathbf{3 , 1 6 0}$ & $\mathbf{4 , 4 4 8}$ \\
\hline US Definition & $\mathbf{3 , 1 6 0}$ &
\end{tabular}

Notes: Full-time Equivalent (FTE) student is a measure of instructional effort (and student activity) that is based on the number of credit hours that students enroll. FTE is based on the Florida definition, which divides undergraduate credit hours by 40 and graduate credit hours by 32 (US definition based on Undergraduate FTE $=30$ and Graduate FTE = 24 credit hours). Funded enrollment as reported in the General Appropriations Act and set by the legislature. Actual enrollment only reports 'state-fundable' FTE as reported by Universities to the Board of Governors in the Student Instruction File (SIF). Totals are actual and may not equal sum of reported student levels due to rounding of student level FTE. 


\section{Section 3 - Enrollment (continued)}

\section{TABLE 3C. Full-Time Equivalent (FTE) Enrollment by Method of Instruction}

2010-11

2011-12

2012-13

TRADITIONAL

LOWER-DIVISION

UPPER-DIVISION

MASTER'S (GRAD I)

DOCTORAL (GRAD II)

TOTAL

748
1,139
197
0

2,085

859
1,082
177
0

2,118
941

1,041

173

1

2,156

HYBRID

$\begin{array}{lccc}\text { LOWER-DIVISION } & 0 & 3 & 7 \\ \text { UPPER-DIVISION } & 0 & 19 & 20 \\ \text { MASTER'S (GRAD I) } & 1 & 2 & 0 \\ \text { DOCTORAL (GRAD II) } & 0 & 0 & 0 \\ \text { TOTAL } & \mathbf{1} & \mathbf{2 5} & \mathbf{2 7}\end{array}$

DISTANCE LEARNING

$\begin{array}{lccc}\text { LOWER-DIVISION } & 199 & 226 & 244 \\ \text { UPPER-DIVISION } & 522 & 632 & 739 \\ \text { MASTER'S (GRAD I) } & 62 & 87 & 112 \\ \text { DOCTORAL (GRAD II) } & 0 & 1 & 0 \\ \text { TOTAL } & 0 & 1 & 1,095\end{array}$

\section{TOTAL}

LOWER-DIVISION
UPPER-DIVISION
MASTER'S (GRAD I)
DOCTORAL (GRAD II)
TOTAL

947
1,661
260
0
2,869

2,869 20 0 (1)

7




\section{Section 4 - Undergraduate Education}

TABLE 4A. Baccalaureate Degree Program Changes in AY 2012-13

\begin{tabular}{|c|c|c|c|c|c|}
\hline Title of Program & $\begin{array}{c}\text { Six-digit } \\
\text { CIP } \\
\text { Code }\end{array}$ & $\begin{array}{c}\text { Degree } \\
\text { Level }\end{array}$ & $\begin{array}{l}\text { Date of } \\
\text { UBOT } \\
\text { Action }\end{array}$ & $\begin{array}{l}\text { Starting } \\
\text { or Ending } \\
\text { Term }\end{array}$ & Comments \\
\hline \multicolumn{6}{|l|}{ New Programs } \\
\hline World Languages and Cultures & 16.0101 & B & $12 / 13 / 2012$ & Fall 2013 & \\
\hline \multicolumn{6}{|l|}{ Terminated Programs } \\
\hline \multicolumn{6}{|l|}{ None } \\
\hline \multicolumn{6}{|l|}{ Inactive Programs } \\
\hline \multicolumn{6}{|l|}{ None } \\
\hline \multicolumn{6}{|c|}{ New Programs Considered By University But Not Approved } \\
\hline None & & & & & \\
\hline
\end{tabular}

Note: This table does not include new majors or concentrations added under an existing degree program CIP Code. This table reports the new and terminated program changes based on Board action dates between May 5, 2012 and May 4, 2013.

New Programs are proposed new degree programs that have been completely through the approval process at the university and, if appropriate, the Board of Governors. Does not include new majors or concentrations added under an existing degree program CIP Code.

Terminated Programs are degree programs for which the entire CIP Code has been terminated and removed from the university's inventory of degree programs. Does not include majors or concentrations terminated under an existing degree program CIP Code if the code is to remain active on the academic degree inventory.

Inactive Programs are degree programs for which enrollments have been temporarily suspended for the entire CIP Code, but the program CIP Code has not been terminated. Does not include majors or concentrations suspended under an existing degree program CIP Code if the code is to remain active on the academic degree inventory and new enrollments in any active major will be reported.

New Programs Considered by University But Not Approved includes any programs considered by the university board of trustees, or any committee of the board, but not approved for implementation. Also include any programs that were returned prior to board consideration by the university administration for additional development, significant revisions, or re-conceptualization; regardless of whether the proposal was eventually taken to the university board for approval. Count the returns once per program, not multiple times the proposal was returned for revisions, unless there is a total re-conceptualization that brings forward a substantially different program in a different CIP Code. 


\section{Section 4 - Undergraduate Education (continued)}

\section{TABLE 4B. Full-time, First-Time-in-College (FTIC) Retention Rates Retained in the Second Fall Term at Same University}

\begin{tabular}{cccccc} 
& $\mathbf{2 0 0 8 - 0 9}$ & $\mathbf{2 0 0 9 - 1 0}$ & $\mathbf{2 0 1 0 - 1 1}$ & $\mathbf{2 0 1 1 - 1 2}$ & $\begin{array}{c}\mathbf{2 0 1 2 - 1 3} \\
\text { Preliminary }\end{array}$ \\
\hline Cohort Size & 379 & 490 & 470 & 576 & 681 \\
\hline$\%$ Retained & $68 \%$ & $71 \%$ & $69 \%$ & $64 \%$ & $60 \%$ \\
\hline $\begin{array}{c}\text { \% Retained } \\
\text { with GPA of 2.0 or higher }\end{array}$ & $62 \%$ & $67 \%$ & $63 \%$ & $61 \%$ & $59 \%$
\end{tabular}

Notes: Cohorts are based on undergraduate students who enter the institution in the Fall term (or Summer term and continue into the Fall term). Percent Retained is based on student enrollment in the Fall term following their first year. Percent Retained with GPA Above 2.0 is based on student enrollment in the Fall term following their first years for those students with a GPA of 2.0 or higher at the end of their first year (Fall, Spring, Summer). The most recent year of Retention data is based on preliminary data (SIFP file) that is comparable to the final data (SIF file) but may be revised in the following years based on changes in student cohorts.

\section{TABLE 4C. Full-time, First-Time-in-College (FTIC) Six-Year Graduation Rates}

\begin{tabular}{lccccc} 
Term of Entry & $\mathbf{2 0 0 3 - 0 9}$ & $\mathbf{2 0 0 4 - 1 0}$ & $\mathbf{2 0 0 5 - 1 1}$ & $\mathbf{2 0 0 6 - 1 2}$ & $\begin{array}{c}\mathbf{2 0 0 7 - 1 3} \\
\text { Preliminary }\end{array}$ \\
\hline \multicolumn{1}{c}{ Cohort Size } & 238 & 160 & 174 & 271 & 236 \\
\hline$\%$ Graduated & $32 \%$ & $30 \%$ & $30 \%$ & $33 \%$ & $41 \%$ \\
\hline$\%$ Still Enrolled & $6 \%$ & $6 \%$ & $7 \%$ & $7 \%$ & $4 \%$ \\
\hline \% Success Rate & $38 \%$ & $36 \%$ & $37 \%$ & $40 \%$ & $45 \%$
\end{tabular}

Notes: Cohorts are based on undergraduate students who enter the institution in the Fall term (or Summer term and continue into the Fall term). Percent Graduated is based on federal rate and does not include students who originally enroll as part-time students, or who transfer into the institution. This metric complies with the requirements of the federal Student Right to Know Act that requires institutions to report the completion status at $150 \%$ of normal time (or six years). Success Rate measures the percentage of an initial cohort of students who have either graduated or are still enrolled at the same university. Since degrees can be awarded after the last semester of coursework, the most recent year of data in this table provides preliminary data that may change with the addition of "late degrees". Late degrees reported in conjunction with the IPEDS Graduation Rate Survey due in mid-April will be reflected in the following year. 
Section 4 - Undergraduate Education (continued)

TABLE 4D. FTIC Progression and Graduation Rates (includes Full-and Part-time students)

4 - Year Rates

Cohort
2005-09

192
2006-10 289
2009-13 2007-11 2008-12 395
Preliminary 496

From Same University

$\%$ Graduated

$\%$ Still Enrolled
$11 \%$

$32 \%$
$15 \%$

$29 \%$
$20 \%$

$28 \%$
$16 \%$

$24 \%$
$23 \%$ $25 \%$

\section{From Other SUS University}

$\begin{array}{lccccc}\% \text { Graduated } & 9 \% & 8 \% & 10 \% & 13 \% & 13 \% \\ \% \text { Still Enrolled } & 19 \% & 18 \% & 14 \% & 18 \% & 17 \%\end{array}$

From State University System

$\begin{array}{lccccc}\% \text { Graduated } & 20 \% & 23 \% & 31 \% & 29 \% & 36 \% \\ \% \text { Still Enrolled } & 51 \% & 47 \% & 42 \% & 42 \% & 42 \% \\ \% \text { Success Rate } & 72 \% & 70 \% & 73 \% & 71 \% & 78 \%\end{array}$

6 - Year Rates

2003-09 2004-10

Cohort

263

176

$32 \%$

$30 \%$

$6 \%$

$30 \%$

$7 \%$

$32 \%$

$7 \%$

$40 \%$

$4 \%$

From Other SUS University

$\begin{array}{lccccc}\% \text { Graduated } & 22 \% & 23 \% & 21 \% & 22 \% & 22 \% \\ \% \text { Still Enrolled } & 3 \% & 5 \% & 7 \% & 6 \% & 2 \%\end{array}$

From State University System
$\%$ Graduated
\% Still Enrolled
$\%$ Success Rate

$54 \%$

$10 \%$

$63 \%$

$53 \%$
$11 \%$
$64 \%$

$51 \%$

$14 \%$

$65 \%$
$54 \%$

$13 \%$

$67 \%$
2007-13 Preliminary 251

Notes: First-time-in-college (FTIC) cohort is defined as undergraduates entering in fall term (or summer continuing to fall) with fewer than 12 hours earned since high school graduation. (1) Cohorts are based on undergraduate students who enter the institution in the Fall term (or Summer term and continue into the Fall term). Students of degree programs longer than four years (eg, PharmD) are included in the cohorts. The initial cohorts are revised to remove students, who have allowable exclusions as defined by IPEDS, from the cohort. (2) Success Rate measures the percentage of an initial cohort of students who have either graduated or are still enrolled. (3) Since degrees can be awarded after the last semester of coursework, the most recent year of data in this table provides preliminary graduation rate data that may change with the addition of "late degrees". Late degrees reported in conjunction with the IPEDS Graduation Rate Survey due in mid-April will be reflected in the following year. 


\section{Section 4 - Undergraduate Education (continued)}

TABLE 4E. AA Transfer Progression and Graduation Rates

\begin{tabular}{rccccc}
$\mathbf{2}-$ Year Rates & $\mathbf{2 0 0 7 - 0 9}$ & $\mathbf{2 0 0 8 - 1 0}$ & $\mathbf{2 0 0 9 - 1 1}$ & $\mathbf{2 0 1 0 - 1 2}$ & $\mathbf{2 0 1 1 - 1 3}$ \\
Preliminary \\
\hline Cohort & 272 & 295 & 289 & 269 & 345
\end{tabular}

From Same University

$\begin{array}{lccccc}\% \text { Graduated } & 25 \% & 18 \% & 22 \% & 23 \% & 22 \% \\ \% \text { Still Enrolled } & 59 \% & 64 \% & 56 \% & 58 \% & 51 \%\end{array}$

From Other SUS University

$\begin{array}{lccccc}\% \text { Graduated } & 2 \% & 3 \% & 1 \% & 2 \% & 1 \% \\ \% \text { Still Enrolled } & 1 \% & 1 \% & 6 \% & 5 \% & 6 \%\end{array}$

From State University System

$\begin{array}{lccccc}\% \text { Graduated } & 27 \% & 22 \% & 24 \% & 25 \% & 23 \% \\ \% \text { Still Enrolled } & 60 \% & 65 \% & 62 \% & 63 \% & 57 \% \\ \% \text { Success Rate } & 87 \% & 87 \% & 86 \% & 88 \% & 80 \%\end{array}$

\begin{tabular}{rccccc}
$\mathbf{4 - Y}$ Year Rates & $\mathbf{2 0 0 5 - 0 9}$ & $\mathbf{2 0 0 6 - 1 0}$ & $\mathbf{2 0 0 7 - 1 1}$ & $\mathbf{2 0 0 8 - 1 2}$ & $\begin{array}{c}\mathbf{2 0 0 9 - 1 3} \\
\text { Preliminary }\end{array}$ \\
\hline Cohort & 294 & 278 & 272 & 295 & 289
\end{tabular}

From Same University

$\begin{array}{lccccc}\% \text { Graduated } & 57 \% & 60 \% & 57 \% & 55 \% & 58 \% \\ \% \text { Still Enrolled } & 9 \% & 9 \% & 13 \% & 11 \% & 8 \%\end{array}$

From Other SUS University

$\begin{array}{lccccc}\% \text { Graduated } & 6 \% & 8 \% & 6 \% & 9 \% & 7 \% \\ \% \text { Still Enrolled } & 1 \% & 0 \% & 2 \% & 1 \% & 2 \%\end{array}$

From State University System

$\begin{array}{lccccc}\text { \% Graduated } & 63 \% & 68 \% & 63 \% & 64 \% & 65 \% \\ \% \text { Still Enrolled } & 10 \% & 10 \% & 15 \% & 12 \% & 10 \% \\ \% \text { Success Rate } & 73 \% & 78 \% & 78 \% & 76 \% & 75 \%\end{array}$

Notes: AA Transfer cohort is defined as undergraduates entering in the fall term (or summer continuing to fall) and having earned an AA degree from an institution in the Florida College System. (1) Cohorts are based on undergraduate students who enter the institution in the Fall term (or Summer term and continue into the Fall term); (2) Success Rate measures the percentage of an initial cohort of students who have either graduated or are still enrolled; (3) since degrees can be awarded after the last semester of coursework, the most recent year of data in this table provides preliminary graduation rate data that may change with the addition of "late degrees". Late degrees reported in conjunction with the IPEDS Graduation Rate Survey due in mid-April will be reflected in the following year. 


\section{Section 4 - Undergraduate Education (continued)}

TABLE 4F. Other Transfer Progression and Graduation Rates

\begin{tabular}{cccccc}
$\mathbf{5}-$ Year Rates & $\mathbf{2 0 0 4 - 0 9}$ & $\mathbf{2 0 0 5 - 1 0}$ & $\mathbf{2 0 0 6 - 1 1}$ & $\mathbf{2 0 0 7 - 1 2}$ & $\begin{array}{c}\mathbf{2 0 0 8 - 1 3} \\
\text { Preliminary }\end{array}$ \\
\hline Cohort Size & 239 & 215 & 278 & 284 & 229
\end{tabular}

\section{From Same University}

$\%$ Graduated

$\%$ Still Enrolled

$\begin{array}{cc}53 \% & 45 \% \\ 4 \% & 4 \%\end{array}$

$53 \%$

$57 \%$

$4 \%$
$48 \%$

$4 \% \quad 6 \%$

\section{From Other SUS University}

$\begin{array}{lccccc}\% \text { Graduated } & 9 \% & 8 \% & 13 \% & 5 \% & 12 \% \\ \% \text { Still Enrolled } & 1 \% & 0 \% & 1 \% & 3 \% & 1 \%\end{array}$

\section{From State University System}

$\begin{array}{lccccc}\% \text { Graduated } & 62 \% & 53 \% & 65 \% & 62 \% & 60 \% \\ \% \text { Still Enrolled } & 5 \% & 4 \% & 6 \% & 7 \% & 7 \% \\ \% \text { Success Rate } & 67 \% & 58 \% & 71 \% & 69 \% & 67 \%\end{array}$

Notes: (1) Cohorts are based on undergraduate students who enter the institution in the Fall term (or Summer term and continue into the Fall term); (2) Success Rate measures the percentage of an initial cohort of students who have either graduated or are still enrolled; (3) since degrees can be awarded after the last semester of coursework, the most recent year of data in this table provides preliminary graduation rate data that may change with the addition of "late degrees". Late degrees reported in conjunction with the IPEDS Graduation Rate Survey due in mid-April will be reflected in the following year. 


\section{Section 4 - Undergraduate Education (continued)} TABLE 4G. Baccalaureate Degrees Awarded

2008-09

Degree Count
671
2009-10

699
2010-11

705
2011-12

736

2012-13

Note: Table 4G represents the counts of distinct baccalaureate degrees. In those cases where baccalaureate degrees are awarded under two different degree CIPs, a distinction is made between "dual degrees" and "dual majors." Dual degrees are counted as separate degrees (i.e., counted twice), and include those cases where the second major differs substantially from the first because either the college is different, the degree designation is different (e.g., BA, BS, BBA, BFA, etc.), or the degree CIP is in a different 2-digit range (e.g., $51^{*}$ vs. $52^{*}$ ); in these cases, the second degree CIP receives a "degree fraction" of 1.0. If these conditions do not apply, the second major is considered a dual major, and the degree associated with it is not counted a second time; in these cases, each dual major degree CIP receives a degree fraction of .5 apiece. The calculation of degree fractions is made according to each institution's criteria. In those rare cases where there are three or more awarded baccalaureate degree CIPs, analogous logic is extended to cover the additional degree CIPs and their corresponding degree fractions.

\section{TABLE 4H. Baccalaureate Degrees Awarded in Programs of Strategic Emphasis}

2008-09

2009-10

2010-11

2011-12

2012-13

Science, Technology,
Engineering, and Math
Health Professions
*only disciplines in critical need

Security and Emergency

Services

Globalization

Education

*only disciplines in critical need

SUBTOTAL

Percentage of All Baccalaureate

Degrees (includes second majors)

31

32

49

39

0

0

47

57

42

45

41

36

66

37

35

36

56

56

103

125

126

187

178

289

$19 \%$

$18 \%$

$27 \%$

$24 \%$

$34 \%$

Notes: This is a count of baccalaureate majors for specific Programs of Strategic Emphasis, as determined by the Board of Governors staff with consultation with business and industry groups and input from universities. A student who has multiple majors in the subset of targeted Classification of Instruction Program codes will be counted twice (i.e., double-majors are included). * This data represents select disciplines within these five areas and does not reflect all degrees awarded within the general field (of education or health). The Board of Governors will review Board staff recommendations to update this list at their November 2013 meeting. Any changes from that meeting will be incorporated into subsequent Accountability Reports. Note: The denominator used in the percentage includes second majors that are not reported in the degree count in table $4 \mathrm{G}$. 


\section{Section 4 - Undergraduate Education (continued)}

\section{TABLE 4I. Baccalaureate Degrees Awarded to Underrepresented Groups}

\section{8-09 2009-10 2010-11 2011-12 2012-13}

\section{Non-Hispanic Black}

$\begin{array}{cccccc}\text { Number of Degrees } & 45 & 36 & 24 & 37 & 53 \\ \text { Percentage of Degrees } & 7 \% & 5 \% & 4 \% & 5 \% & 7 \%\end{array}$

\section{Hispanic}

\begin{tabular}{cccccc} 
Number of Degrees & 52 & 56 & 72 & 66 & 83 \\
Percentage of Degrees & $8 \%$ & $8 \%$ & $11 \%$ & $9 \%$ & $10 \%$ \\
\hline -Grant Recipients & & & & & \\
\hline Number of Degrees & 156 & 248 & 276 & 333 & 418 \\
Percentage of Degrees & $23 \%$ & $36 \%$ & $40 \%$ & $46 \%$ & $51 \%$
\end{tabular}

Note: Non-Hispanic Black and Hispanic do not include students classified as Non-Resident Alien or students with a missing race code. Students who earn two distinct degrees in the same term are counted twice - whether their degrees are from the same six-digit CIP code or different CIP codes. Students who earn only one degree are counted once - even if they completed multiple majors or tracks. Percentage of Degrees is based on the number of baccalaureate degrees awarded to non-Hispanic Black and Hispanic students divided by the total degrees awarded - excluding those awarded to nonresident aliens and unreported.

Pell-Grant recipients are defined as those students who have received a Pell grant from any SUS Institution within six years of graduation - excluding those awarded to non-resident aliens, who are only eligible for Pell grants in special circumstances. Percentage of Degrees is based on the number of baccalaureate degrees awarded to Pell recipients, as shown above, divided by the total degrees awarded - excluding those awarded to non-resident aliens.

Notes on Trends: In 2007, the US Department of Education re-classified the taxonomy for self-reported race/ethnicity categories and allowed universities a two-year phase-in process before all institutions were required to report based on the new categories for the 2010-11 academic year. This reclassification will impact trends. 


\section{Section 4 - Undergraduate Education (continued) TABLE 4J. Baccalaureate Degrees Without Excess Credit Hours}

2008-09

FTIC

.

2009-10

2010-11

2011-12

2012-13*

AA Transfers

.

.

. $67 \%$

$58 \%$

Other Transfers

TOTAL

.

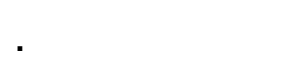

$65 \%$

.

$37 \%$

$52 \%$

Notes: This table is based on statute 1009.286 (see link), and excludes certain types of student credits (ie, accelerated mechanisms, remedial coursework, non-native credit hours that are not used toward the degree, non-native credit hours from failed, incomplete, withdrawn, or repeated courses, credit hours from internship programs, credit hours up to 10 foreign language credit hours for transfer students in Florida, and credit hours earned in military science courses that are part of the Reserve Officers' Training Corps (ROTC) program). This metric is not the same as the Excess Hours Surcharge, which has multiple cohorts with varying fee rates. This table reports the percentage of baccalaureate degrees awarded within $110 \%$ of the catalog hours required for a degree based on the Board of Governors Academic Program Inventory. This calculation is based on Hours To Degree data submitted by universities to the Board of Governors and excludes recent graduates who have already earned a baccalaureate degree.

Note*: Improvements were made to data collection process beginning with 2012-13 data.

\section{TABLE 4K. Undergraduate Course Offerings}

Fall 2008 Fall 2009 Fall $2010 \quad$ Fall $2011 \quad$ Fall 2012

$\begin{array}{llllll}\begin{array}{c}\text { Number of } \\ \text { Course Sections }\end{array} & 342 & 340 & 387 & 366 & 391\end{array}$

\section{Percentage of Undergraduate Course Sections by Class Size}

\begin{tabular}{lccccc}
\hline Fewer than 30 Students & $55 \%$ & $52 \%$ & $53 \%$ & $51 \%$ & $59 \%$ \\
\hline 30 to 49 Students & $34 \%$ & $39 \%$ & $39 \%$ & $41 \%$ & $32 \%$ \\
\hline 50 to 99 Students & $11 \%$ & $9 \%$ & $8 \%$ & $8 \%$ & $8 \%$ \\
\hline 100 or More Students & $0 \%$ & $0 \%$ & $0 \%$ & $0 \%$ & $1 \%$
\end{tabular}

Notes: This data is based on Common Data Set (CDS) definitions. According to CDS, a "class section is an organized course offered for credit, identified by discipline and number, meeting at a stated time or times in a classroom or similar setting, and not a subsection such as a laboratory or discussion session. Undergraduate class sections are defined as any sections in which at least one degree-seeking undergraduate student is enrolled for credit. Exclude distance learning classes and noncredit classes and individual instruction such as dissertation or thesis research, music instruction, or one-to-one readings. Exclude students in independent study, co-operative programs, internships, foreign language taped tutor sessions, practicums, and all students in one-on-one classes. 


\section{Section 4 - Undergraduate Education (continued)}

TABLE 4L. Percentage of Undergraduate Credit Hours Taught by Instructor Type

\begin{tabular}{lccccc} 
& $\mathbf{2 0 0 8 - 0 9}$ & $\mathbf{2 0 0 9 - 1 0}$ & $\mathbf{2 0 1 0 - 1 1}$ & $\mathbf{2 0 1 1 - 1 2}$ & $\mathbf{2 0 1 2 - 1 3}$ \\
\hline Faculty & $68 \%$ & $69 \%$ & $71 \%$ & $65 \%$ & $63 \%$ \\
\hline Adjunct Faculty & $31 \%$ & $31 \%$ & $28 \%$ & $35 \%$ & $36 \%$ \\
\hline Graduate Students & $1 \%$ & $0 \%$ & $0 \%$ & $0 \%$ & $0 \%$ \\
\hline Other Instructors & $0 \%$ & $0 \%$ & $1 \%$ & $0 \%$ & $0 \%$
\end{tabular}

Note: The total number of undergraduate state fundable credit hours taught will be divided by the undergraduate credit hours taught by each instructor type to create a distribution of the percentage taught by each instructor type. Four instructor types are defined as faculty (pay plans 01, 02, and 22), OPS faculty (pay plan 06), graduate student instructors (pay plan 05), and others (all other pay plans). If a course has more than one instructor, then the university's reported allocation of section effort will determine the allocation of the course's total credit hours to each instructor. The definition of faculty varies for Tables 4L, 4M and 4N. For Faculty Teaching Undergraduates, the definition of faculty is based on pay plans 01, 02, and 22.

\section{TABLE 4M. Student/Faculty Ratio}

\section{Fall 2008 Fall $2009 \quad$ Fall $2010 \quad$ Fall $2011 \quad$ Fall 2012}

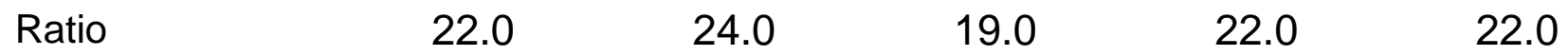

Note: This data is based on Common Data Set (CDS) definitions. This is the Fall ratio of full-time equivalent students (full-time plus $1 / 3$ part time) to fulltime equivalent instructional faculty (full time plus $1 / 3$ part time). In the ratio calculations, exclude both faculty and students in stand-alone graduate or professional programs such as medicine, law, veterinary, dentistry, social work, business, or public health in which faculty teach virtually only graduatelevel students. Do not count undergraduate or graduate student teaching assistants as faculty. 


\section{Section 5 - Graduate Education}

\section{TABLE 5A. Graduate Degree Program Changes in AY 2012-13}

\begin{tabular}{|c|c|c|c|c|c|c|}
\hline Title of Program & $\begin{array}{c}\text { Six-digit } \\
\text { CIP } \\
\text { Code }\end{array}$ & $\begin{array}{l}\text { Degree } \\
\text { Level }\end{array}$ & $\begin{array}{l}\text { Date of } \\
\text { UBOT } \\
\text { Action }\end{array}$ & $\begin{array}{l}\text { Starting } \\
\text { or Ending } \\
\text { Term }\end{array}$ & $\begin{array}{l}\text { Date of } \\
\text { Board of } \\
\text { Governors } \\
\text { Action }\end{array}$ & Comments \\
\hline \multicolumn{7}{|l|}{ New Programs } \\
\hline Psychology & 42.0101 & M & 6/14/2013 & Fall 2013 & & \\
\hline \multicolumn{7}{|c|}{ Terminated Programs } \\
\hline \multicolumn{7}{|c|}{ None } \\
\hline \multicolumn{7}{|l|}{ Inactive Programs } \\
\hline \multicolumn{7}{|l|}{ None } \\
\hline \multicolumn{7}{|c|}{ New Programs Considered By University But Not Approved } \\
\hline None & & & & & & \\
\hline
\end{tabular}

Note: This table does not include new majors or concentrations added under an existing degree program CIP Code. This table reports the new and terminated program changes based on Board action dates between May 5, 2012 and May 4, 2013.

New Programs are proposed new degree programs that have been completely through the approval process at the university and, if appropriate, the Board of Governors. Does not include new majors or concentrations added under an existing degree program CIP Code.

Terminated Programs are degree programs for which the entire CIP Code has been terminated and removed from the university's inventory of degree programs. Does not include majors or concentrations terminated under an existing degree program CIP Code if the code is to remain active on the academic degree inventory.

Inactive Programs are degree programs for which enrollments have been temporarily suspended for the entire CIP Code, but the program CIP Code has not been terminated. Does not include majors or concentrations suspended under an existing degree program CIP Code if the code is to remain active on the academic degree inventory and new enrollments in any active major will be reported.

New Programs Considered by University But Not Approved includes any programs considered by the university board of trustees, or any committee of the board, but not approved for implementation. Also include any programs that were returned prior to board consideration by the university administration for additional development, significant revisions, or re-conceptualization; regardless of whether the proposal was eventually taken to the university board for approval. Count the returns once per program, not multiple times the proposal was returned for revisions, unless there is a total re-conceptualization that brings forward a substantially different program in a different CIP Code. 
Section 5 - Graduate Education (continued)

TABLE 5B. Graduate Degrees Awarded

\begin{tabular}{lccccc} 
& $\mathbf{2 0 0 8 - 0 9}$ & $\mathbf{2 0 0 9 - 1 0}$ & $\mathbf{2 0 1 0 - 1 1}$ & $\mathbf{2 0 1 1 - 1 2}$ & $\mathbf{2 0 1 2 - 1 3}$ \\
\hline \multicolumn{1}{c}{ TOTAL } & $\mathbf{1 5 8}$ & $\mathbf{1 4 8}$ & $\mathbf{1 4 5}$ & $\mathbf{1 4 6}$ & $\mathbf{1 4 3}$ \\
\hline Masters and Specialist & 158 & 148 & 145 & 146 & 143 \\
\hline Research Doctoral & 0 & 0 & 0 & 0 & 0 \\
Professional Doctoral & 0 & 0 & 0 & 0 & 0 \\
\hline a) Medicine & 0 & 0 & 0 & 0 & 0 \\
b) Law & 0 & 0 & 0 & 0 & 0 \\
c) Pharmacy & 0 & 0 & 0 & 0 & 0
\end{tabular}

Note: The total number of Professional Doctoral degrees includes other programs that are not specifically identified in lines $a, b$, and $c$.

\section{TABLE 5C. Graduate Degrees Awarded in Areas of Strategic Emphasis}

\section{8-09 2009-10 2010-11 2011-12 2012-13}

\begin{tabular}{|c|c|c|c|c|c|}
\hline $\begin{array}{l}\text { Science, Technology, } \\
\text { Engineering and Math }\end{array}$ & 1 & 2 & 10 & 6 & 8 \\
\hline $\begin{array}{l}\text { Health Professions } \\
\text { *only disciplines in critical need }\end{array}$ & 0 & 0 & 0 & 0 & 0 \\
\hline $\begin{array}{l}\text { Security and Emergency } \\
\text { Services }\end{array}$ & 0 & 0 & 0 & 0 & 0 \\
\hline Globalization & 0 & 0 & 0 & 0 & 0 \\
\hline $\begin{array}{l}\text { Education } \\
\text { *only disciplines in critical need }\end{array}$ & 54 & 36 & 36 & 22 & 33 \\
\hline SUBTOTAL & 55 & 38 & 46 & 28 & 41 \\
\hline $\begin{array}{l}\text { Percent of All } \\
\text { Graduate Degrees }\end{array}$ & $35 \%$ & $26 \%$ & $32 \%$ & $19 \%$ & $29 \%$ \\
\hline
\end{tabular}

Notes: This is a count of graduate degrees awarded within specific Areas of Strategic Emphasis, as determined by the Board of Governors staff with consultation with business and industry groups and input from universities. A student who has multiple majors in the subset of targeted Classification of Instruction Program codes will be counted twice (i.e., double-majors are included). ${ }^{*}$ This data represents select disciplines within these five areas and does not reflect all degrees awarded within the general field (of education or health). Note: The denominator used in the percentage includes second majors that are not reported in the degree count in table 5B. 


\section{Section 6 - Research and Economic Development}

TABLE 6A. Research and Development

2007-08 2008-09 2009-10 2010-11 2011-12

\section{R\&D Expenditures}

Total (S\&E and non-S\&E)

$(\$ 1,000$ s)

Federally Funded

$(\$ 1,000$ s)

Percent Funded

From External Sources

Total R\&D Expenditures

Per Full-Time, Tenured,

Tenure-Earning Faculty

Member (\$)
Campus R\&D data

is not available

for these

historical years.
$\$ 4,419 \quad \$ 3,978$

$\$, 2058$

$\$ 2,799$

$\$ 2,570$

$61 \%$

$55 \%$

$59 \%$

$\$ 51,988 \quad \$ 49,725 \quad \$ 66,120$

\section{Technology Transfer}

Invention Disclosures

U.S. Patents Issued

Patents Issued Per 1,000

Full-Time, Tenured and

Tenure-Earning Faculty

Licenses/ Options Executed

Reported at the USF System level.

Licensing Income

Received (\$)

Number of Start-Up

Companies

Note: R\&D Expenditures are based on the National Science Foundation's annual Survey of R\&D Expenditures at Universities and Colleges (data include Science \& Engineering and non-Science \& Engineering awards). Percent Funded from External Sources is defined as funds from federal, private industry and other sources (non-state and non-institutional funds). Total R\&D expenditures are divided by fall, full-time tenured/tenure-track faculty as reported to IPEDS (FGCU includes both tenured/tenure-track and non-tenure/track faculty). The fall faculty year used will align with the beginning of the fiscal year, so that (e.g.) 2007 FY R\&D expenditures are divided by fall 2006 faculty. Technology Transfer data are based on the Association of University Technology Managers Annual Licensing Survey. Licensing Income Received refers to license issue fees, payments under options, annual minimums, running royalties, termination payments, amount of equity received when cashed-in, and software and biological material end-user license fees of $\$ 1,000$ or more, but not research funding, patent expense reimbursement, valuation of equity not cashed-in, software and biological material end-user license fees of less than $\$ 1,000$, or trademark licensing royalties from university insignia. Number of Start-up Companies that were dependent upon the licensing of University technology for initiation. 